\title{
THE DIFFERENTIATION AND DISTRIBUTION OF THE PARATYPHOID-ENTERITIDIS GROUP. VI
}

\author{
AVIAN PARATYPHOID BACILLI: A COMPARATIVE. STUDY \\ OF B. PULLORUM AND B. SANGUINARIUM
}

F. W. MuLsow

Fram the Department of Hygiene and Bacteriology, University of Chicago

Two organisms of the paratyphoid-enteritidis group designated, respectively, as B. pullorum and B. sanguinarium, are considered responsible for certain diseases of the domestic fowl. They are generally regarded as quite widely distributed thruout the United States. We have, nevertheless, little definite knowledge at present as to the prevalence of the diseases caused by these organisms. Smith and Ten Broeck ${ }^{1}$ have suggested that $B$. sanguinarium may be the cause of the occasional reports of gastro-intestinal disturbances following the eating of meat of fowls. The feeding experiments of Rettger, Hull and Sturges ${ }^{2}$ suggest that B. pullorum may be the cause of food poisoning. The disease in fowls produced by $B$. sanguinarium resembles clinically that caused by $B$. avisepticus, and $\mathrm{Hadley}^{3}$ statec that many of the laboratory cultures of $B$. avisepticus are really B. gallinarum or some member of the paratyphoid-enteritidis group. Several investigators have observed the close relationship of these organisms to each other, their antigenic and cultural relations to B. typhosus, and the general relationship of these organisms to the paratyphoid-enteritidis group. In view of these facts it appears that further study of these organisms is quite desirable.

B. sanguinarium was first isolated in the United States in 1894 by Smith, ${ }^{1}$ from an epidemic among fowls in Rhode Island. Moore isolated the same organism in 1895 from diseased fowls in Washington, D. C., Virginia, and Maryland and gave the first detailed description of the organism and the disease produced by it. $\mathrm{He}$ at first called the disease "infectious leukemia" because of the reduction in number of the red blood cells and the increase in the number of white blood cells. Curtis ${ }^{5}$ studied an outbreak of the disease in Rhode Island in 1901 and called the disease "fowl typhoid," which is the name accepted today. B. sanguinarium has been isolated more recently

Received for publication March 13, 1919.

1 Jour. Med. Research, 1915, 31, p. 503.

2 Jour. Exper. Med., 1916, 23, p. 475.

8. Jour. Bacteriol., 1918, 3, p. 286.

Twelfth and Thirteenth Annual Reports, Bur. An. Ind., U. S. Dept. of Agric., p. 185.

5 R. I. Exper. Sta., Bull. 87, 1902. 
from several epidemics in the New England states. Pfeiler and Rehse ${ }^{6}$ in 1913 described what was apparently the same organism as the cause of an epidemic among fowls in Germany. They named it B. typhi gallinarum alcalifaciens, apparently not knowing that it had been previously described by Moore and others. Pfeiler and Roepke ${ }^{7}$ have isolated this organism from a second epidemic in Germany and have given quite a thoro description of it, which shows that it is undoubtedly the same organism described by Moore. Lignières and $\mathrm{Zabala}^{\mathrm{B}}$ isolated a paratyphoid-like organism from fowls during an epidemic among fowls in South America and from their description, the bacterium appears to be very similar if not identical to B. sanguinarium. It also appears that Klein, as has been suggested by Hadley in a personal communication, described the same organism in 1889 under the name B. gallinarum as the cause of an epidemic in England. Altho his description is not as complete as has been given in recent years by Moore and others, yet his description and my own work with this organism indicate that it is identical with the one described by Moore. Since the organism studied by Klein apparently has the priority in nomenclature, it appears that the name of the bacillus of fowl typhoid should be $B$. gallinarum. Final decision on this point, however, should await a classificatory revision of the whole group. In order to avoid confusion at this time I shall use the name $B$. sanguinarium.

B. pullorum as the cause of the disease known as "bacillary white diarrhea" was first isolated in 1899 by Rettger ${ }^{10}$ from young chicks which had died of the disease. There has been some doubt, at times, as to whether this organism was really the cause of white diarrhea of chicks. Morse ${ }^{11}$ in 1909 observed that this disease was due to a coccidium. A recent Farmers' Bulletin (957) issued by the Bureau of Animal Industry, Washington, D. C., states that a clinical disease called "white diarrhea" of chicks may be caused by B. pullorum, $B$. avisepticus, a coccidium, or Aspergillus fumigatus. During the past few years B. pullorum has been the cause of epidemics among chicks in many parts of the United States. It has been observed, however, much more frequently in the New England states. Young chicks under 72 hours of age are considered to be especially susceptible, altho Jones ${ }^{12}$ and Hadley ${ }^{13}$ have described epidemics among adult fowls, due to this organism.

The pathologic changes produced by B. pullorum have been thoroly studied by Gage and Martin. ${ }^{14}$ They state that the disease in small chicks is a septicemia and that the minute necrotic foci in the liver, spleen, and pancreas are the most characteristic lesions. If the chick recovers from an infection it may become a permanent carrier. Horton ${ }^{15}$ reports the apparent recovery of a bantam hen which evidently had an ovarian infection, since two of her eggs contained the organism and the agglutination test. with her serum was positive; however, a year later the organisms could not be isolated from the eggs and the agglutination reaction was negative. The ovary seems to be the most

6 Mitth. d. Kaiser-Wilhelms Inst. f. Landwirtschaft in Bromberg, 1913, No. 4, p. 306.

7 Centralbl. f. Bakteriol., 1917, 79, p. 125. (Abstracted in Jour. Comp. Path. and Therap., 1917, 30, p. 263.)

8 Hoare, A System of Veterinary Med., 1913, 1, p. 466.

- Centralbl. f. Bakteriol., 1889, 5, p. 689.

${ }_{10}$ N. Y. Med. Jour., 1900, 71, p. 803.

${ }^{11}$ U. S. Dept. of Agric., B. A. I. Circular 128 (1909).

12 Jour. Med. Research, 1913, 27, p. 471.

13 R. I. Exper. Sta., Bull, 172.

14 Jour. Med. Research, 1916, 34, p. 149.

15 Jour. Bacteriol;; 1916, I, p. 625. 
frequent site of the infection in adult hens and often has a pathologic appearance. However, apparently normal ova may carry the organism to the full formed egg.

In the present study of B. pullorum and B. sanguinarium comparisons have been made with typical strains of members of the paratyphoid-enteritidis group, and with B. typhosus and B. avisepticus. Typical representatives of the paratyphoid-enteritidis group were obtained from Jordan ${ }^{16}$ who has made an extensive study of this group. For the history of these strains the reader may refer to his publications. Typical strains of B. typhosus were taken from stock cultures. It was somewhat more difficult to secure typical strains of $B$. avisepticus, hence it was necessary to devote some- time to the study of this organism. Altho an organism was described under this name as early as 1879 by Toussaint and in 1880 by Pasteur, yet there are very few data concerning its fermentative action on the carbohydrates and, furthermore, there is considerable disagreement as to many of its characteristics, such as fermentative action, indol production, and pathogenesis. It is generally agreed, however, that this organism is a short gram-negative, nonmotile rod which does not liquefy gelatin. It is usually described as having a marked tendency to stain deeper at the poles, especially when stained from the blood of an infected fowl. The tendency to polar staining, however, is markedly reduced when grown on artificial mediums or when inoculated into rabbits; hence it is often quite difficult to distinguish' it from B. sanguinarium, which frequently stains lightly in the central part. B. avisepticus is usually highly virulent for rabbits, but may soon lose this virulence when grown on artificial mediums. This may explain in part the contradictory results observed by various investigators concerning its pathogenesis. In view of these facts it seemed advisable to include the reaction of strains of $B$. avisepticus in the tables and in certain discussions.

The organisms which have been studied in the present work were obtained from as widely different sources as possible and were tested for purity by plating on Endo medium. Three colonies were picked from the Endo plates and compared with the original, in milk containing brom-cresol-purple as an indicator and in dextrose, lactose and maltose broth fermentation tubes containing an indicator to show any change in the acidity as well as gas production. The source of the cultures is given in table 1 .

16 Jour. Infect. Dis., 1917, 20, p. 457. 
TABLE 1

Source of Culture

\begin{tabular}{|c|c|c|c|c|c|}
\hline \multirow{2}{*}{ Strain } & \multirow{2}{*}{ Original Label } & \multirow{2}{*}{ Received from } & \multicolumn{3}{|c|}{ Isolation } \\
\hline & & & Date & $\begin{array}{l}\text { Loca- } \\
\text { tion }\end{array}$ & By whom \\
\hline \multicolumn{6}{|l|}{ B. sangui. } \\
\hline 1 & B. of Fowl typhoid I & Dr. Theobald Smith... & 1895 & $\begin{array}{l}\text { Va. or } \\
\text { Md. }\end{array}$ & Dr. V. A. Moore \\
\hline 2 & B. of Fowl typhoid II & Dr. Theobald Smith... & 1894 & R. I. & Dr. Theobald Smith \\
\hline $\begin{array}{r}3 \\
11\end{array}$ & $\begin{array}{l}\text { B. sangurnarum } \\
\text { "Taylor" }\end{array}$ & $\begin{array}{l}\text { Am. Mus. Nat. Hist. .. } \\
\text { Dr. W. A. Hagan..... }\end{array}$ & Apr. '14 & $\begin{array}{l}\text { N. Y. } \\
\text { Oalif. }\end{array}$ & $\begin{array}{l}\text { Dr. Unas. Krumweide } \\
\text { Dr. W. J. Taylor }\end{array}$ \\
\hline 12 & $\begin{array}{l}\text { B. sanguinarium } \\
\text { "Smith IV" }\end{array}$ & Dr. W. A. Hagan...... & $\ldots \ldots \ldots$ & $\ldots \ldots$ & Dr. Theobald Smith \\
\hline 13 & $\begin{array}{l}\text { B. gallinarum No. } 51 \\
\text { or Rettgers cult. "S" }\end{array}$ & Dr. P. B. Hadley.. & $\ldots \ldots \ldots$ & Conn. & Dr. L. F. Rettger \\
\hline 14 & B. gallinarum No. 108 & Dr. P. B. Hadley....... & Oct. '14 & R. I. & Dr. P. B. Hadley \\
\hline 15 & B. gallinarum No. 110 & Dr. P. B. Hadley.. & Oct.' '14 & R. I. & Dr. P. B. Hadley \\
\hline 50 & B. gallinarum No. 42 & Dr. P. B. Hadley.. & $\ldots \ldots \ldots$ & R. I. & Dr. P. B. Hadley \\
\hline 51 & B. gallinarum No. 45 & Dr. P. B. Hadley.. & $\ldots \ldots \ldots$ & R. I. & Dr. P. B. Hadley \\
\hline 52 & B. gallínarum No. 66 & Dr. P. B. Hadley.. & $\ldots \ldots \ldots$ & Conn. & \\
\hline 53 & B. gallinarum No. 69 & Dr. P. B. Hadley.. & & N. Y. & \\
\hline 54 & B. gallinarum No. 115 & Dr. P. B. Hadley...... & 1892 & & Dr. V. A. Moore \\
\hline 88 & B. gallinarum No. 88 & Dr. P. B. Hadley...... & 1888 & $\begin{array}{l}\text { Kent, } \\
\text { Eng. }\end{array}$ & Dr. E. Klein \\
\hline 55 & $\begin{array}{c}\text { From cholera-like } \\
\text { epidemic }\end{array}$ & Dr. Chas. Murray..... & 1917 & Iowa & Dr. Chas. Murray \\
\hline $\begin{array}{l}47 \\
56\end{array}$ & $\begin{array}{l}\text { B. sanguinarium } \\
\text { From cholera-like } \\
\text { epidemic }\end{array}$ & Dr. Chas Murra & $\begin{array}{l}\text { Apr. '18 } \\
\text { Oet. '18 }\end{array}$ & $\begin{array}{l}\text { Ill. } \\
\text { Iowa }\end{array}$ & $\begin{array}{l}\text { F. W. Mulsow } \\
\text { Dr. Chas. Murray }\end{array}$ \\
\hline 57 & B. sanguinarium & & Nov. '18 & Ill. & F. W. Mulsow \\
\hline $\begin{array}{l}40 \\
41\end{array}$ & B. avisepticus No. 549 & Am. Mus Nat. Hist. $\therefore$ & 1908 & Colo. & State Vet. Coll. \\
\hline & $\begin{array}{l}\text { From cholera-like } \\
\text { epidemic among } \\
\text { wild ducks }\end{array}$ & Univ. of Kansas... & 1916 & Kans. & Dr. B. J. Clawson \\
\hline B. avisep- & B. avisepticus "Park" & Univ. of Kansas... & ....... & & Dr. W. H. Park \\
\hline $\begin{array}{l}44 \\
45 \\
46 \\
48\end{array}$ & $\begin{array}{l}\text { B. avisepticus } \\
\text { B. avisepticus } \\
\text { B. avisepticus } \\
\text { B. avisepticus No. } 62 \\
\text { (Kral No. 3) }\end{array}$ & $\begin{array}{l}\text { B. A. I., Wash., D. C. } \\
\text { L. M. Roderick........ } \\
\text { L. M. Roderick........ } \\
\text { Dr. P. B. Hadley..... }\end{array}$ & $\begin{array}{c}\text { Feb. '18 } \\
\text { Mar. '18 } \\
\ldots \ldots\end{array}$ & $\begin{array}{l}\text { R. I. } \\
\text { N. D. } \\
\text { N. D. } \\
\cdots+\text {. }\end{array}$ & $\begin{array}{l}\text { Dr. P. B. Hadley } \\
\text { L. M. Roderick } \\
\text { L. M. Roderick } \\
\text { Kral's laboratory }\end{array}$ \\
\hline 49 & B. avisepticus No. 91 & Dr. P. B. Hadley.. & & R. I. & Dr. P. B. Hadley \\
\hline $\begin{array}{l}71 \\
72\end{array}$ & $\begin{array}{l}\text { B. avisepticus } \\
\text { B. avisepticus }\end{array}$ & $\ldots \ldots \ldots \ldots \ldots \ldots \ldots$ & $\begin{array}{l}\text { Nov. '18 } \\
\text { Oct.'18 }\end{array}$ & $\begin{array}{l}\text { Ill. } \\
\text { Ill. }\end{array}$ & $\begin{array}{l}\text { F. W. Mulsow } \\
\text { F. W. Mulsow }\end{array}$ \\
\hline B. pul- & & & & & \\
\hline$\underset{25}{\operatorname{lorum}}$ & $\begin{array}{l}\text { B. gallinarum } \\
\text { No. 102A }\end{array}$ & & & R. I. & Dr. P. B. Hadley \\
\hline $\begin{array}{l}\mathbf{4} \\
\mathbf{5}\end{array}$ & $\begin{array}{l}\text { B. pullorum IV } \\
\text { B. pullorum No. } 5\end{array}$ & $\begin{array}{l}\text { Dr. Theobald Smith... } \\
\text { Dr. O. M. Haring..... }\end{array}$ & July '14 & Calíf. & $\begin{array}{l}\text { Dr. Theobald Smith } \\
\text { Dr. C. M. Haring }\end{array}$ \\
\hline 6 & B. pullorum VI & Dr. Theobald Smith... & $\ldots \ldots \ldots$ & & Dr. Theobald Smith \\
\hline $\begin{array}{l}7 \\
8\end{array}$ & $\begin{array}{l}\text { B. pullorum } \\
\text { B. pullorum }\end{array}$ & $\begin{array}{l}\text { Dr. G. D. Horton....... } \\
\text { Dr. G. D. Horton.... }\end{array}$ & $\begin{array}{l}1917 \\
1917\end{array}$ & Mo. & Dr. G. D. Horton \\
\hline 9 & B. pullorum No. 9 & Dr. $\mathrm{C} . \mathrm{M}$. Haring.......... & Jan. '17 & Calif. & Dr. O. M. Haring \\
\hline 10 & B. pullorum & Dr. L. F. Rettger...... & 1909 & Conn. & Dr. L. F. Rettger \\
\hline $\begin{array}{l}16 \\
18\end{array}$ & $\begin{array}{l}\text { B. pullorum } \\
\text { B. pullorum "K Rut- }\end{array}$ & $\begin{array}{l}\text { Dr. L. F. Rettger...... } \\
\text { Dr. W. A. Hagan...... }\end{array}$ & 1916 & Conn. & Dr. L. F. Rettger \\
\hline 19 & B. pullorum J2 & Dr. W. A. Hagan...... & ... & $\mathbf{N} . \mathbf{Y}$. & Dr. F. S. Jones \\
\hline 20 & B. pullorum & Dr. W. A. Hagan.. & & N. Y. & Dr. F. S. Jones \\
\hline 21 & B. pullorum 17 & Dr. P. B. Hadley.. & & R. I. & Dr. P. B. Hadley \\
\hline 22 & B. pullorum 34 & & $\ldots \ldots \ldots$ & R. I. & Dr. P. B. Hadley \\
\hline 23 & B. pullorum 56 & Dr. P. B. Hadley....... & & R. I. & Dr. P. B. Hadley \\
\hline 24 & B. pullorum 99 & Dr. P. B. Hadley....... & & R. I. & Dr. P. B. Hadley \\
\hline 26 & B. pullorum E4 & Dr. L. F. Rettger...... & 1910 & Conn. & Dr. L. F. Rettger \\
\hline 27 & B. pullorum (W. R.) & Dr. L. F. Rettger...... & 1911 & Conn. & Dr. L. F. Rettger \\
\hline 28 & B. pullorum $\mathbf{B}$ & Dr. L. F. Rettger...... & 1916 & Conn. & Dr. L. F. Rettger \\
\hline 29 & B. pullorum W & Dr. L. F. Rettger...... & 1917 & Conn. & Dr. L. F. Rettger \\
\hline $\begin{array}{l}30 \\
31\end{array}$ & $\begin{array}{l}\text { B. pullorum } 403 \\
\text { B. pullorum }\end{array}$ & $\begin{array}{l}\text { Am. Mus. Nat. Hist. .. } \\
\text { Dr. F, D. Beckwith. }\end{array}$ & $\stackrel{1911}{\operatorname{Jan}^{\prime} 18}$ & N. Y. & $\begin{array}{l}\text { Dr. F. S. Jones } \\
\text { Dr. F. D. Beckwith }\end{array}$ \\
\hline 32 & B. pullorum & B. A. I., Wash., D. O. & & D. 0 . & \\
\hline
\end{tabular}




\section{DISTRIBUTION}

In order to learn more concerning the distribution of these organisms and to secure cultures from as widely different sources as possible, letters were written to every agricultural experiment station in the United States. I wish to express my thanks at this time for cultures and information received from the many correspondents.

From publications and letters from the experiment stations it appears that investigations concerning these organisms have been carried on in only a few states. Hence our knowledge of the diseases caused by these organisms in the United States is quite fragmentary and rests on scattered observations. A few states as Connecticut, Rhode Island and Massachusetts have made quite thoro studies of these organisms and methods of controlling their spread. Their distribution, as obtained from the correspondence and bulletins of the several experiment stations is summarized in table 2 .

TABLE 2

Distributron of B. Pullorum and B. Sanguinarium by States

\begin{tabular}{|c|c|c|c|c|c|}
\hline \multirow{2}{*}{$\begin{array}{c}\text { No } \\
\text { Epidemics } \\
\text { Observed }\end{array}$} & \multirow{2}{*}{$\begin{array}{c}\text { No } \\
\text { Studies } \\
\text { Made }\end{array}$} & \multicolumn{2}{|c|}{ Occurrence of B. pullorum } & \multicolumn{2}{|c|}{ Occurrence of B. sanguinarium } \\
\hline & & Rare & Frequent & Rare & Frequent \\
\hline $\begin{array}{l}\text { Ala. } \\
\text { Colo. } \\
\text { Mich. } \\
\text { Minn. } \\
\text { Miss. } \\
\text { N. J. } \\
\text { N. C. } \\
\text { *N. D. } \\
\text { *Obio } \\
\text { Okla. } \\
\text { \#. D. } \\
\text { Vt. } \\
\text { W. Va. }\end{array}$ & $\begin{array}{l}\text { Ariz. } \\
\text { Fla. } \\
\text { Idaho } \\
\text { Ky. } \\
\text { Maine } \\
\text { Md. } \\
\text { Mont. } \\
\text { Nev. } \\
\text { N. Mex. } \\
\text { S. O. } \\
\text { Utah } \\
\text { Va. }\end{array}$ & $\begin{array}{l}\text { "Iowa } \\
\text { Kans. } \\
\text { Nebr. } \\
\text { Texas } \\
\text { Wisc. } \\
\text { La. }\end{array}$ & $\begin{array}{l}\text { Calif. } \\
\text { Conn. } \\
\text { *Del. } \\
\text { *Ill. } \\
\text { Ind. } \\
\text { Mass. } \\
\text { Mo. } \\
\text { N. H. } \\
\text { N. Y. } \\
\text { Ore. } \\
\text { Penn. } \\
\text { R. I. }\end{array}$ & $\begin{array}{l}\text { Calif. } \\
\text { Del. } \\
\text { Iowa } \\
\text { Mo. } \\
\text { Penn. } \\
\text { Wash. } \\
\text { Wyo. }\end{array}$ & $\begin{array}{l}\text { Conn. } \\
\text { Mass } \\
\text { R. I. }\end{array}$ \\
\hline
\end{tabular}

* Letters from these states contain the information that chicken cholera is rather prevalent.

From table 1 it appears that B. sanguinarium has been isolated comparatively few times, but as has been suggested by Taylor ${ }^{17}$ and $\mathrm{Hadley}^{3}$ and from my own observations, it appears that this organism is more frequently the cause of epidemics in fowls than it is generally considered to be. Thus, some cultures which $I$ have received from other laboratories that were labelled $\mathrm{B}$. avisepticus have proven to be B. sanguinarium. Hence many cholera-like epidemics attributed to $B$. avisepticus may very likely be due to $B$. sanguinarium.

17 Jour. Am. Vet. Med. Assn., 1916, 49, p. 35. 


\section{CULTURAL CHARACTERISTICS}

Quite thoro descriptions of the staining, morphological, and cultural characteristics on the ordinary mediums of $B$. sanguinarium and B. pullorum have been made by Moore ${ }^{4}$ and Rettger, ${ }^{18}$ respectively. It seems necessary to mention only a few of their most characteristic reactions. They are gram-negative, nonmotile rods, and belong to the paratyphoid-enteritidis group. B. sanguinarium does not, in general, take the ordinary stains as readily as $B$. pullorum, and often when stained with fuchsin the central portion is only faintly stained. The growth on agar and gelatin resembles that of the other members of the paratyphoid-enteritidis group, altho in my work the strains of B. pullorum have not grown as a rule as luxuriant on these mediums as B. sanguinarium or other members of this group.

INDOL

In Moore's original article it is stated that B. sanguinarium produces a slight amount of indol, but other investigators using the more accurate modern methods have not been able to detect indol formation by this organism. B. pullorum has never been observed to produce indol.

The test for indol production in the present study has been made in two ways, on three different occasions. The first time the organisms were grown in the standard peptone solution for 1-5 days, respectively. In the second and third tests the organisms were grown in standard meat extract broth and in meat infusion broth, respectively. The test for indol has been made in two ways, with the same results in all cases.

1. By Ehrlich's paradimethyl-amido-benzaldehyde reaction.

2. By the use of vanillin as described by Nelson (J. Biol. Chem., 1916, 24 , p. 527).

Control tests were made by testing uninoculated broth, and cultures of $\mathrm{B}$. Coli.

Indol was not produced by any strains of B. pullorum or B. sanguinarium. Seven strains of $B$. avisepticus produced indol, but two strains, 40 and 42 , which were labelled B. avisepticus did not form indol. These two strains have proven to be similar to strains of B. sanguinarium in many other respects; hence, I have called them B. sanguinarium. There is some dispute as to the ability of B. avisepticus to produce indol. Lignières ${ }^{10}$ states that indol is not produced by this organism, while $\mathrm{Kitt}^{19}$ and others maintain that indol is pro-

18 Jour. Med. Research, 1908, 18, p. 227.

10 Handb. d. pathogen, Mikroorganismen, 1913, 6, p. 39. 
duced by B. avisepticus. My results have been in accord with those of Kitt.

\section{HYDROGEN SULPHID}

Since it has been observed by Burnet and Weissenbach, ${ }^{21}$ Jordan and Victorson, ${ }^{22}$ and others, that certain members of the paratyphoidenteritidis group differ in their ability to produce hydrogen sulphid, it seemed desirable to test the avian strains in this respect.

The test for hydrogen sulphid production was made by placing 2 drops of a $10 \%$ aqueous solution of lead acetate into tubes containing $10 \mathrm{cc}$ of sterile freshly prepared nutrient agar cooled to about $50 \mathrm{C}$. The tubes were then cooled and stabs were made by passing the inoculating needle between the wall of the tube and the agar. Tests have been made at three different times. The first time meat extract was used in the preparation of the agar and only the strains from 1-20 were tested. In the second, meat infusion broth was used in the preparation of the agar. The third was made according to the method of Jordan and Victorson, ${ }^{22}$ with the exception that my medium contained Armour's peptone instead of Witte's.

All the strains of B. pullorum and B. sanguinarium, except B. pullorum No. 19 and B. sanguinarium No. 3 and No. 14 produced a blackening of the medium along the line of inoculation in 24 hours when tested by the method of Jordan and Victorson. In the second test the B. sanguinarium No. 14 was positive in 24 hours and B. sanguinarium No. 54 was positive only after 48 hours. These strains which do not form hydrogen sulphid in 24 hours are typical in other respects. On the whole, these avian strains are like $B$. enteritidis and $B$. paratyphoid B in regular hydrogen sulphid production.

\section{MILK}

It has been stated by Smith and Ten Broeck, ${ }^{1}$ Rettger and Koser, ${ }^{23}$ and others that $B$. sanguinarium produces an alkaline reaction in milk in a few days, while B. pullorum remains acid. Their observations extended over a period of about two weeks.

In the present study I used certified milk from which the cream had been removed. The milk was sterilized by heating in the autoclave for $15-20 \mathrm{~min}$ utes at $10 \mathrm{lbs}$. of pressure. Either $7 \%$ of a $1 \%$ solution of Merck's litmus or $1 \%$ of a $0.5 \%$ solution of brom-cresol-purple prepared as recommended by Clark and Lubs, was added to the milk before sterilization. The two indicators have given practically the same results altho the brom-cresol-purple appears to be the more delicate and is not so easily reduced.

${ }_{21}$ Compt. rend. Soc. de biol., 1915, 78, p. 565.

22 Jour. Infect. Dis., 1917, 21, p. 571.

23 Jour. Med. Research, 1917, 35, p. 443. 
All strains produce a slight acidity in $24-48$ hours. The strains of B. sanguinarium from alkali, however; after 2-5 days. There are some exceptions to this which are shown in table 3. All strains of B. pullorum produce alkali after 60 -days' incubation. Some strains showed an alkaline reaction as early as 4 days, while others did not become alkaline until about 60 days. The reaction varies considerably with different lots of milk.

Since certain strains of B. pullorum form alkali as early as some strains of B. sanguinarium it appears that we cannot differentiate between these two organisms by any change produced in the reaction of milk. Altho, in general, B. sanguinarium produces alkali earlier than B. pullorum. The B. avisepticus produces a slight acidity in 48 hours which persists for 90 days, but the organisms are usually dead after about 2 weeks' incubation. Thus it may be distinguished from the other organisms by its action on milk.

The digestive action of these organisms on the casein was tested with milk which contained no indicator. B. sanguinarium, in general, completely digested the casein in about 2 weeks, altho with some strains digestion was not complete before 6 weeks. The strains of B. pullorum vary even more in their digestive action; with some strains digestion was complete in 2 weeks, while others have failed in this respect in 90 days. Therefore these organisms cannot be differentiated by their digestive action on milk.

Details of the changes in the reaction of milk produced by these organisms are given in table 3 .

\section{Fermentation of Carbohydrates}

The fermentation reactions of $B$. sanguinarium and $B$. pullorum have been studied quite extensively by Rettger and Koser, ${ }^{23}$ and more recently by Krumwiede and Kohn. The former investigators state that the principal fermentative differences between these organisms are: (1) The production of gas by B. pullorum in dextrose, levulose, galactose, and mannite, and the inability of B. sanguinarium to form gas in any of the carbohydrates, and (2) the production of acid in maltose, dulcite, and dextrin by $B$. sanguinarium and the failure of $B$. pullorum to ferment these substances. Similar reactions have been observed by Goldberg ${ }^{25}$ and others.

The ability of B. pullorum to form gas in some carbohydrates seems to vary with different strains and at times the same strain will show variations in its ability to produce gas. Rettger isolated a strain which did not form gas in any of the carbohydrates. He has also observed variations in gas pro-

24 Ibid., 1917, 36, p. 509.

25 Jour. Am. Vet. Med. Assn., 1917, 51, p. 203. 
duction with other strains. Variation in the ability to form gas has also been noted by Krumwiede and $\mathrm{Kohn},{ }^{24}$ who secured a non-gas producing strain from Smith, but in their work this strain was observed to produce gas.

TABLE 3

Changes Produced in the Acidity of Milk Containing Brom-Cresol-Purple, BY DAYS

\begin{tabular}{|c|c|c|c|c|c|c|c|c|c|c|c|c|c|}
\hline & & 1 & 2 & 3 & 4 & 5 & 7 & 10 & 14 & 21 & 30 & 60 & 90 \\
\hline \multirow[t]{20}{*}{ B. sanguinarium } & 1 & + & $+c$ & . & .. & - & .. & $\cdots$ & $\cdots$ & $\ldots$ & - & . & $\cdots$ \\
\hline & 2 & + & $+c-$ & . & - & . & .. & .. & $\therefore$ & .. & 一 & $\ldots$ & $\ldots$ \\
\hline & 3 & + & $+\mathrm{c}-$ & . & 一 & . & . & . & . & . & - & $\ldots$ & $\ldots$ \\
\hline & 11 & $+c-$ & $\cdots$ & . & . & . & 一 & . & .. & . & 一 & . & $\cdots$ \\
\hline & 12 & $+\mathrm{e}-$ & .. & .. & $\mathrm{Nc}-$ & - & . & - & .. & $\cdots$ & 一 & $\cdots$ & $\cdots$ \\
\hline & 13 & + & $\cdots$ & $\cdots$ & $\cdots$ & $+\mathrm{e}-$ & 一 & $\cdots$ & $\because$ & $\cdots$ & - & $\cdots$ & -. \\
\hline & 14 & $\begin{array}{c}+c- \\
+\end{array}$ & $\because$ & 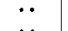 & $\because$ & Ne- & $\overline{\mathrm{Na}}-$ & $\ddot{-}$ & - & $\cdots$ & - & $\cdots$ & $\because$ \\
\hline & $\begin{array}{l}15 \\
40\end{array}$ & $\begin{array}{c}+ \\
+\mathrm{c}-\end{array}$ & $\because$ & $\because$ & $\ddot{\mathrm{NC}}$ & - & $\ldots$ & . & $\ddot{*}$ & $\ddot{*}$ & - & $\because$ & $\because$ \\
\hline & 41 & $+c-$ & .. & .. & $\ldots$ & .. & - & $\therefore$ & .. & $\ldots$ & - & $\ldots$ & $\ddot{*}$ \\
\hline & 42 & $+\mathrm{c}-$ & . & .. & $\therefore$ & - & . & . & $\cdots$ & .. & - & . & . \\
\hline & 47 & $+c-$ & . & . & $\mathrm{Ne}-$ & - & . & . & . & .. & - & .. & .. \\
\hline & 50 & + & .. & . & . & .. & $\cdots$ & $\cdots$ & .. & $\cdots$ & + & - & .. \\
\hline & 51 & $+c-$ & $\cdots$ & $\because$ & $\cdots$ & - - & 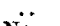 & . & .. & 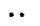 & - & $\ldots$ & . \\
\hline & 52 & + & $\cdots$ & $+c-$ & . & .. & $\mathrm{Ne}-$ & 一 & .. & $\cdots$ & - & .. & $\cdots$ \\
\hline & 53 & + & $\cdots$ & . & $\cdots$ & $\cdots$ & $\cdots$ & $\cdots$ & .. & . & + & - & .. \\
\hline & 54 & $+\mathrm{c}-$ & $\cdots$ & $\cdots$ & * & - & $\cdots$ & $\cdots$ & $\cdots$ & $\cdots$ & - & $\cdots$ & $\cdots$ \\
\hline & 55 & $+\mathrm{c}-$ & $\because$ & .. & *. & - & $\cdots$ & $\cdots$ & $\cdots$ & $\therefore$ & 一 & - & $\cdots$ \\
\hline & 88 & + & $+c-$ & $\ddot{\theta}$ & $\cdots$ & $\rightarrow$ & -. & $\cdots$ & $\cdots$ & $\cdots$ & 一 & $\cdots$ & $\cdots$ \\
\hline & 56 & + & $\cdots$ & $\mathrm{Ne}-$ & - & -・ & $\cdots$ & $\cdots$ & $\cdots$ & $\cdots$ & - & $\cdots$ & $\cdots$ \\
\hline & 57 & + & $\ddot{+}$ & $\cdots$ & $\cdots$ & - & $\because$ & $\cdots$ & $\cdots$ & $\cdots$ & $\overline{1}$ & $\ddot{r}$ & $\ddot{1}$ \\
\hline \multirow{6}{*}{ B. avisepticus } & $\begin{array}{l}44 \\
45\end{array}$ & $\begin{array}{l}+ \\
+\end{array}$ & $\begin{array}{c}+ \\
+\end{array}$ & $\cdots$ & . & ・. & $\because$ & $\cdots$ & $\because$ & $\because$ & + & + & $\dot{t}$ \\
\hline & 46 & $\begin{array}{l}+ \\
+\end{array}$ & + & $\because$ & $\because$ & $\ddot{x}$ & $\ddot{*}$ & $\ddot{0}$ & $\because$ & $\ddot{\ddot{\theta}}$ & + & ì & + \\
\hline & 48 & + & + & .. & 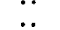 & .. & .. & . & .. & .. & + & + & + \\
\hline & 49 & + & + & . & . & .. & $\cdots$ & . & $\ldots$ & .. & + & + & + \\
\hline & 71 & + & + & .. & .. & .. & .. & $\cdots$ & .. & .. & + & $\ldots$ & $\ldots$ \\
\hline & 72 & + & + & $\cdots$ & . & . & .. & $\cdots$ & $\cdots$ & .. & + & $\ldots$ & .. \\
\hline \multirow[t]{22}{*}{ B. pullorum } & 4 & + & $+c-$ & $\cdots$ & 一 & . & .. & $\cdots$ & . & .. & 一 & .. & . \\
\hline & 5 & + & $+c-$ & $\cdots$ & .. & . & $\cdots$ & 一 & .. & . & - & .. & . \\
\hline & 6 & + & . & $\cdots$ & $\cdots$ & $\cdots$ & •. & $\cdots$ & * & •. & + & - & $\cdots$ \\
\hline & 7 & + & $\cdots$ & . & .. & $\cdots$ & .. & $\cdots$ & . & . & + & - & . \\
\hline & 8 & + & $\cdots$ & $\cdots$ & $\cdots$ & $\cdots$ & $\cdot$ & $\cdots$ & $\cdots$ & $\cdots$ & $t$ & - & $\cdots$ \\
\hline & 9 & + & $\cdots$ & $\cdots$ & $\cdots$ & $\cdots$ & $\cdots$ & $\cdots$ & $\cdots$ & . & - & $\cdots$ & $\cdots$ \\
\hline & 10 & + & $\cdots$ & $\cdots$ & $\cdots$ & $\cdots$ & .. & - & $\cdots$ & $\cdots$ & + & - & $\cdots$ \\
\hline & 16 & + & $\cdots$ & $\cdots$ & $\cdots$ & $\cdots$ & $\cdots$ & $\cdots$ & -. & $\cdots$ & - & . & . \\
\hline & 18 & $\begin{array}{l}+ \\
+\end{array}$ & $\ddot{+e}$ & $\because$ & $\ddot{-}$ & - & $\because$ & $\because$ & $\cdots$ & $\because$ & - & $\cdots$ & $\cdots$ \\
\hline & 20 & $+e-$ & . & $\because$ & 二 & $\because$ & $\because$ & $\ddot{*}$ & 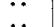 & $\because$ & 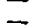 & $\because$ & $\cdots$ \\
\hline & 21 & + & . & $\therefore$ & .. & - & . & .. & $\ddot{*}$ & $\because$ & - & $\ddot{0}$ & $\because$ \\
\hline & 22 & + & .. & .. & .. & .. & .. &.. & $+c-$ & - & - & .. & $\therefore$ \\
\hline & 23 & + & $\cdots$ & .. & .. & . & $\ldots$ & $+c-$ & - & .. & - & . & .. \\
\hline & 24 & $+c-$ & .. & . & 一 & $\ldots$ & . & . & $\ldots$ & .. & - & $\cdots$ & .. \\
\hline & 25 & + & . & $\cdots$ & $\cdots$ & . & $\cdots$ & . & - & $\ldots$ & $一$ & .. & . \\
\hline & 26 & + & $\therefore$ & .. & $\cdots$ & $\therefore$ & $\cdots$ & $\cdots$ & $\cdots$ & $\cdots$ & - & $*$ & $\cdots$ \\
\hline & 27 & + & $+c-$ & $\because$ & $\cdots$ & Ne- & - & $\cdots$ & $\cdots$ & $\cdots$ & - & . & - \\
\hline & 28 & + & .. & $+\mathrm{e}-$ & .. & $\mathrm{Ne}-$ & - & $\cdots$ & . & $\cdots$ & - & $\cdots$ & $\cdots$ \\
\hline & 29 & + & $\cdots$ & $\cdots$ & $\cdots$ & .. & $\cdots$ & $\cdots$ & $\cdots$ & . & + & 一 & .. \\
\hline & 30 & + & $\cdots$ & $\cdots$ & $\because$ & $\cdots$ & $\cdots$ & $\cdots$ & - & . & $\overrightarrow{\mathbf{N}}$ & $\because$ & .. \\
\hline & 31 & i & $\cdots$ & $\cdots$ & $\because$ & $\ddot{0}$ & $\cdots$ & $\cdots$ & $\cdots$ & $\cdots$ & N & - & $\cdots$ \\
\hline & 32 & + & $\cdots$ & $\cdots$ & $\cdots$ & +6 & $\cdots$ & $\cdots$ & - & $\cdots$ & 一 & $\cdots$ & . \\
\hline
\end{tabular}

Symbols: $+=$ acid.

$+c-=$ body of tube acid and cream ring alkaline.

$\mathrm{Ne}-=$ body of tube neutral and cream ring alkaline.

- = alkaline reaction thruout medium.

In my own work the medium used in determining the fermentative reactions has been standard nutrient broth made from meat extract to which was added $0.5 \%$ of the carbohydrate to be tested. Andrade's indicator was used as the indicator of acid production in some of the earlier tests but bromcresol-purpie has been used in all the later tests. The indicator was added 
to the medium which was then placed in tubes containing inverted vials. The medium was sterilized by heating in the autoclave for 10-15 minutes at 10 lbs. of pressure.

Some preliminary tests were made in which the amount of acid produced was determined by titration. But since this required considerable amounts of the medium in order to make observations at intervals over a period of several days and gave no information of importance other than was given by the indicator method, it has been discontinued.

The fermentative reactions are summarized in tables 4 and 5 .

TABLE 4

Actd and Gas Production in the Carbohydrates by B. Pullorum

\begin{tabular}{|c|c|c|c|}
\hline $\begin{array}{c}\text { Acid and Gas } \\
\text { Positive }\end{array}$ & \multicolumn{2}{|c|}{$\begin{array}{c}\text { Acid and Gas } \\
\text { Negative }\end{array}$} & $\begin{array}{c}\text { Gas Variable and } \\
\text { Acid Positive }\end{array}$ \\
\hline $\begin{array}{l}\text { Dextrose } \\
\text { Levulose } \\
\text { Galactose } \\
\text { Mannite } \\
\text { Mannose } \\
\text { Arabinose } \\
\text { Rhamnose }\end{array}$ & $\begin{array}{l}\text { Lactose } \\
\text { Saccharose } \\
\text { *Maltose } \\
\text { Raffinose } \\
\text { Inulin }\end{array}$ & $\begin{array}{l}\text { Erythrit } \\
\text { Dextrin } \\
\text { Dulcite } \\
\text { Inosite } \\
\text { Salicin }\end{array}$ & $\begin{array}{l}\text { Xylose } \\
\text { Sorbite }\end{array}$ \\
\hline
\end{tabular}

* Some strains of B. pullorum apparently ferment maltose, and B. avisepticus produces a very slight amount of acid sometimes.

TABLE 5

Acid Production in the Carbohydrates by B. Sanguinarium and B. Avisepticus

\begin{tabular}{|c|c|c|c|}
\hline \multicolumn{2}{|c|}{ B. sanguinarium } & \multicolumn{2}{|c|}{ B. avisepticus } \\
\hline Positive & Negative & Positive & Negative \\
\hline $\begin{array}{l}\text { Dextrose } \\
\text { Levulose } \\
\text { Galactose } \\
\text { Mannite } \\
\text { Mannose } \\
\text { Arabinose } \\
\text { Rhamnose } \\
\text { Dulcite } \\
\text { Maltose } \\
\text { Xylose } \\
\text { *Dextrin }\end{array}$ & $\begin{array}{l}\text { Lactose } \\
\text { Saceharose } \\
\text { Raffinose } \\
\text { Inulin } \\
\text { Erythrit } \\
\text { Inosite } \\
\text { Salicin } \\
\text { tSorbite }\end{array}$ & $\begin{array}{l}\text { Dextrose } \\
\text { Levulose } \\
\text { Galactose } \\
\text { Mannite } \\
\text { Mannose } \\
\text { Arabinose } \\
\text { Sorbite } \\
\text { Saceharose } \\
\text { Xylose }\end{array}$ & $\begin{array}{l}\text { Lactose } \\
\text { Rhamnose } \\
\text { †Maltose } \\
\text { Dulcite }\end{array}$ \\
\hline
\end{tabular}

* Only a very slight amount of acid was formed by some strains, which made it practically impossible to distinguish from $B$. pullorum by the use of this carbohydrate alone.

+ Acid production in sorbite varies with different strains as will be shown in a subsequent table.

$\ddagger$ Some strains of $B$. pullorum apparently ferment maltose, and $B$. avisepticus produces a very slight amount of acid sometimes.

The fermentative reactions, however, are not as uniform as tables 4 and 5 indicate. In some cases it is rather difficult to differentiate strains of $B$. pullorum from $B$. sanguinarium by their fermentative capacities.

It is generally considered that maltose fermentation differentiates between $B$. pullorum and $B$. sanguinarium. Altho Krumwiede and 
Kohn have observed that certain strains of $B$. pullorum produce a slight amount of acid in maltose after several days' incubation, they suggest that this is probably due to hydrolysis rather than any latent ability to ferment this carbohydrate. In my own work some strains of B. pullorum have produced a slight amount of acid after several days' incubation. This does not appear to be due to hydrolysis alone, since those strains which produce acid after several days' incubation do not form acid sooner in tubes which have been incubated for 3 weeks than in those freshly made up. Strains 20 and 32 have produced acid and gas in maltose somewhat irregularly. Subcultures of colonies picked from plates of these two strains are variable in their fermentation of maltose. In other respects these strains are typical. There also appears to be some variation in the fermentation of maltose by $B$. sanguinarium. Two strains have not fermented maltose promptly. They have fermented it only slightly after 10 days' incubation. The reaction in maltose and a few other carbohydrates, in which the reactions are quite variable, are given in table 6 .

Dulcite is not fermented by any strain of B. pullorum, while all strains of B. sanguinarium but one ferment it promptly; Strain 14 ferments it rather slowly. There appears to be less variation in the fermentative action of these avian strains on dulcite than in any other carbohydrate.

Dextrin is fermented only slightly by most strains of B. sanguinarium and is not fermented at all by certain strains at different times. On the other hand, some strains of B. pullorum appear to ferment this carbohydrate slightly. Krumwiede and $\mathrm{Kohn}^{24}$ have also observed that the fermentation of dextrin by $B$. sanguinarium is irregular. They believe that the results depend on the constituents of the sample, since other members of the paratyphoid-enteritidis group varied in a similar manner.

Acid is uniformly, tho slowly, produced in sorbite by B. pullorum, but the ability to form gas varies. B. sanguinarium is irregular in its action on sorbite. Some strains do not produce acid in 30 days, and in no case is acid formed before 5-7 days. The strains of $B$. avisepticus ferment this carbohydrate promptly.

Rhamnose is promptly fermented by all strains of B. pullorum, altho the gas production is somewhat irregular. The inability of B. sanguinarium to form acid promptly in rhamnose is quite uniform with all strains and may serve in a measure to differentiate between 
B. sanguinarium and B. pullorum. The strains of B. avisepticus have not fermented this carbohydrate.

The chief fermentative differences between B. pullorum and B. sanguinarium are:

1. The production of gas by most strains of B. pullorum in several of the carbohydrates and the inability of $\mathrm{B}$. sanguinarium to produce gas in any carbohydrate.

2. The fermentation of dulcite and maltose by $B$. sanguinarium and the inability of B. pullorum to ferment these carbohydrates. A few strains of B. pullorum attack maltose slightly and two strains of B. sanguinarium produce acid very slowly in this sugar. Also Strains 20 and 32 of $\mathrm{B}$. pullorum irregularly produce acid and gas in maltose.

3. The strains of $B$. sanguinarium studied ferment rhamnose slowly while the strains of $B$. pullorum ferment it promptly.

4. Some strains of B. sanguinarium do not produce acid in sorbite, while all strains of $B$ : pullorum produce acid.

\section{Agglutination}

The agglutinative relationship of these organisms to each other and to B. typhosus was first observed by Smith and Ten Broeck. ${ }^{1}$ They also observed that these organisms were not agglutinated by serums of rabbits immunized toward the different types of B. dysenteriae, and to B. cholera suis. Rettger and $\mathrm{Koser}^{23}$ and Krumwiede and Kohn have also observed the close agglutinative relationship of $B$. sanguinarium and $B$. pullorum to B. typhosus. Pfeiler and Roepke have observed that an immune serum for the fowl typhoid organism did not agglutinate B. typhosus or B. suipestifer but agglutinated B. paratyphosus A and B, B. enteritidis and B. psittacosis in dilutions as high as $1: 400$.

In my work all determinations have been made by mixing $1 \mathrm{cc}$ of the various dilutions of the serum in small tubes, with $1 \mathrm{cc}$ of a 24-hour agar slant growth suspended in sufficient salt solution to give a uniform turbidity. The mixtures were incubated for 2 hours at $37 \mathrm{C}$., then placed in the ice chest for about 20 hours, when readings were made.

Agglutination tests with serum of rabbits immunized toward Strains 4, 7, 9, 19, 22 and 31 of B. pullorum, and Strains 2, 3, 11, 40 and 47 of B. sanguinarium have not shown any agglutinative differences between B. pullorum and B. sanguinarium. The strains with which I have worked have not been agglutinated when treated with a 1:250 dilution of serums from rabbits immunized toward typical strains of B. paratyphosus A and B, B. suipestifer, B. abortus equinus, and the Shiga and Flexner types of $B$. dysenteriae.

The agglutinative relation to $B$. typhosus, which has been observed by other investigators, has been observed in my own work. The 
immune serum for B. typhosus 189-a stock culture-has not, as a rule, agglutinated the avian strains in as high dilutions as has that for B. typhosus "Hopkins," when the titer of the serums was the same. All strains of $B$. pullorum and B. sanguinarium have been tested with these two serums. Some typical reactions are given in table 7 .

TABLE 6

Acid and Gas Production in Broth Containing 0.5\% of the Carbohydrate and $1 \%$ of a $0.5 \%$ Solution of Brom-Cresol-Purple

\begin{tabular}{|c|c|c|c|c|c|c|c|c|c|c|c|c|c|c|}
\hline \multirow{2}{*}{ Strain } & \multicolumn{2}{|c|}{ Dextrose } & \multicolumn{2}{|c|}{ Maltose } & \multicolumn{2}{|c|}{ Arabinose } & \multicolumn{2}{|c|}{ Rhamnose } & \multicolumn{2}{|c|}{ Sorbite } & \multicolumn{2}{|c|}{ Xylose } & \multicolumn{2}{|c|}{ Duleite } \\
\hline & Acid & Gas & Acid & Gas & Acid & Gas & Acid & Gas & Acid & Gas & Acid & Gas & Acid & Gas \\
\hline \multirow{2}{*}{$\begin{array}{l}\text { B. sangui- } \\
\text { narium } 1\end{array}$} & & & & & & & & & & & & & & \\
\hline & + & - & + & - & + & - & +3 & - & +10 & - & + & - & + & 一 \\
\hline $\begin{array}{l}2 \\
3\end{array}$ & $\dot{+}$ & 二 & + & 二 & $\stackrel{+}{+}$ & $=$ & +3 & $\underline{-}$ & $\begin{array}{r}+7 \\
+10\end{array}$ & $\overline{-}$ & + & E & $t$ & $\overline{-}$ \\
\hline 11 & + & 一 & +3 & - & + & - & +3 & - & +10 & 二 & + & - & $t$ & -- \\
\hline 12 & + & - & + & - & + & - & +3 & - & +14 & - & +2 & - & + & - \\
\hline 13 & + & 一 & + & - & + & - & +2 & - & +10 & - & +2 & - & + & - \\
\hline 14 & + & - & +21 & - & + & - & +2 & - & +21 & - & + & - & +14 & - \\
\hline 15 & + & - & + & - & + & - & +2 & - & +21 & - & + & - & + & - \\
\hline 40 & + & 一 & + & - & + & - & +3 & - & - & - & + & - & + & - \\
\hline 41 & + & - & + & 一 & + & - & +3 & - & +21 & - & + & - & + & - \\
\hline 42 & + & - & + & - & + & - & +2 & - & +21 & - & + & - & + & - \\
\hline 47 & + & 一 & + & - & + & - & +3 & - & +14 & 一 & + & - & + & - \\
\hline 50 & + & - & +14 & - & + & - & +5 & - & - & - & + & - & + & - \\
\hline 51 & + & - & + & - & + & - & +3 & - & - & - & + & - & + & - \\
\hline 52 & + & - & + & - & + & - & +5 & - & +10 & - & + & - & + & - \\
\hline 53 & + & - & + & - & + & - & +7 & - & +21 & 一 & + & - & + & - \\
\hline 54 & + & 一 & + & - & + & - & +5 & - & +21 & - & + & - & + & \\
\hline 55 & + & - & + & - & + & - & +10 & - & $\rightarrow$ & - & + & - & + & - \\
\hline B. pul- ${ }^{88}$ & + & - & + & - & + & - & +5 & - & +21 & - & + & - & + & - \\
\hline \multirow{21}{*}{$\begin{array}{l}\text { B. puil- } \\
\text { lorum }\end{array}$} & + & + & +30 & - & + & + & + & + & +6 & +7 & + & +2 & - & - \\
\hline & + & + & +21 & - & + & +2 & + & + & +7 & +14 & + & +2 & - & - \\
\hline & \pm & + & $\bar{z}$ & - & \pm & $\bar{t}$ & + & +2 & $\begin{array}{l}+10 \\
+10\end{array}$ & - & + & - & - & $=$ \\
\hline & \pm & \pm & $\bar{z}$ & $=$ & +2 & \pm & + & $\frac{+2}{-2}$ & $\begin{array}{l}+10 \\
+7\end{array}$ & $\overline{-}$ & + & $=$ & Z & $\bar{z}$ \\
\hline & + & + & $=$ & 二 & + & + & + & +2 & $\begin{array}{r}1 \\
+10\end{array}$ & 二 & $t$ & +6 & 二 & $\overline{-}$ \\
\hline & + & +2 & \pm 80 & - & + & - & + & +4 & +10 & - & +6 & - & - & - \\
\hline & + & +2 & - & - & +2 & +2 & + & - & +7 & - & +6 & - & - & - \\
\hline & + & + & +10 & 一 & + & + & + & + & +10 & - & + & +2 & - & - \\
\hline & + & + & +30 & & + & + & + & 一 & +7 & +7 & + & +2 & - & - \\
\hline & + & + & +21 & \pm 21 & + & +2 & + & + & +7 & +7 & + & +2 & - & - \\
\hline & + & + & & - & + & +3 & $t$ & + & +6 & & & & - & - \\
\hline & + & + & +30 & - & + & - & + & +2 & +6 & +14 & +2 & +6 & - & - \\
\hline & + & + & - & - & + & - & + & + & +10 & & + & & - & - \\
\hline & + & + & - & 一 & + & +2 & + & + & +10 & +14 & + & +3 & - & - \\
\hline & + & + & 一 & - & + & - & + & +2 & +10 & - & + & 7 & 一 & 一 \\
\hline & $t$ & + & +30 & $\bar{z}$ & +2 & $\overline{7}$ & + & +3 & $\begin{array}{l}+10 \\
+7\end{array}$ & 二 & + & +3 & $=$ & $=$ \\
\hline & + & +2 & 二 & $\bar{z}$ & + & +2 & + & +3 & $\begin{array}{r}+7 \\
+10\end{array}$ & +30 & +3 & 12 & - & - \\
\hline & + & 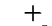 & +30 & - & + & +2 & + & +2 & +10 & - & +2 & - & - & - \\
\hline & + & +2 & & 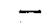 & + & + & + & +2 & +10 & & +2 & & - & - \\
\hline & $T$ & + & - & & $T$ & + & + & + & +10 & +10 & + & +6 & - & - \\
\hline & + & + & +3 & +3 & + & + & + & + & +10 & +10 & + & +3 & - & - \\
\hline & + & - & \pm & - & + & - & - & - & +2 & - & +5 & - & $\rightarrow$ & - \\
\hline 4 & + & - & \pm & 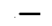 & i & - & - & & +2 & - & +7 & - & - & - \\
\hline 46 & + & - & $\mp$ & 一 & + & - & - & & +2 & - & +5 & - & - & - \\
\hline 48 & + & - & \pm & - & + & - & - & - & + & - & \pm 7 & - & & - \\
\hline 49 & + & - & \pm & - & + & - & - & - & +2 & - & \pm 7 & - & - & - \\
\hline
\end{tabular}

Symbols: $t=$ acid or gas production in 24 hours.

- $=$ no acid or gas production in 30 days.

A flgure following a $(+)$ indicates the number of days after inoculation when acid or gas was first observed.

$\pm \stackrel{=}{=}$ very slight acid production or irregularity in acid production. 
TABLE 7

Agglutination of B. Pullorum and. B. Sanguinarium with Serums from Rabits IMMUNIZED TO B. TYPHOSUS

\begin{tabular}{|c|c|c|c|c|c|c|c|c|}
\hline & \multirow{2}{*}{\multicolumn{4}{|c|}{$\begin{array}{c}\begin{array}{c}\text { Serum of Rabbit Treated } \\
\text { with B. typhosus Hopkins } \\
\text { Titer 1:5000 }\end{array} \\
\text { Dilution of Serum }\end{array}$}} & \multirow{2}{*}{\multicolumn{4}{|c|}{$\begin{array}{c}\begin{array}{c}\text { Serum of Rabbit Treated } \\
\text { with B. typhosus } 189 \\
\text { Titer } 1: 6000\end{array} \\
\text { Dilution of Serum }\end{array}$}} \\
\hline & & & & & & & & \\
\hline & 500 & 1000 & 2500 & 5000 & 500 & 1000 & 2500 & 5000 \\
\hline 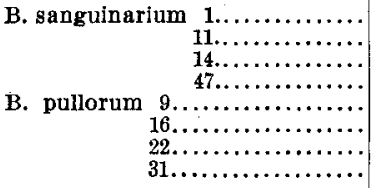 & $\begin{array}{l}++ \\
+++ \\
++ \\
+++ \\
+++ \\
+++ \\
+++ \\
+++\end{array}$ & $\begin{array}{l}+ \\
++ \\
++ \\
+++ \\
+++ \\
+ \\
++ \\
++\end{array}$ & $\begin{array}{l}+ \\
++ \\
+ \\
++ \\
+ \\
+ \\
+ \\
+\end{array}$ & $\begin{array}{l}\overline{+} \\
\overline{+} \\
\frac{+}{+} \\
\frac{+}{-}\end{array}$ & $\begin{array}{l}++ \\
++ \\
++ \\
+++ \\
++ \\
++ \\
++ \\
++\end{array}$ & $\begin{array}{l}+ \\
++ \\
++ \\
++ \\
+ \\
+ \\
++ \\
++\end{array}$ & $\begin{array}{l}\overline{+} \\
+ \\
++ \\
+ \\
+ \\
+\end{array}$ & 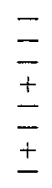 \\
\hline
\end{tabular}

Symbols: $+++=$ complete agglutination.

++ E marked agglutination.

$+\ldots$ slight agglutination.

The agglutinative relation between $B$. enteritidis and these organisms has not been reported by other investigators, except that Pfeiler and Roepke observed that immune serums for two strains of $B$. enteritidis with a titer of $1: 10,000$ and $1: 16,000$, respectively, agglutinated the "bacillus of fowl typhoid" in a dilution as high as 1:800. In my work, immune serums toward two strains of B. enteritidis (Jordan's strains 52 and 205) have agglutinated all the avian strains. Some strains of B. pullorum and B. sanguinarium, however, have been only slightly agglutinated in dilutions of $1: 250$ when the titer was $1: 10,000$. In general, the serum of the rabbit immunized to B. enteritidis (52) has agglutinated the avian strains in higher dilutions than the immune serum for B. enteritidis (205). Some typical reactions are given in table 8 .

TABLE 8

Agglutination of B. Pullorum and B. Sanguinarium with Serums from Rabeits IMMUNE TO B. ENTERITIDIS

\begin{tabular}{|c|c|c|c|c|c|c|c|c|}
\hline & \multirow{2}{*}{\multicolumn{4}{|c|}{$\begin{array}{c}\begin{array}{c}\text { Serum of Rabbit Treated } \\
\text { with } \mathrm{B} \text {. enteritidis } 52 \\
\text { Titer } 1: 16,000\end{array} \\
\text { Dilution of Serum }\end{array}$}} & \multirow{2}{*}{\multicolumn{4}{|c|}{$\begin{array}{c}\begin{array}{c}\text { Serum of Rabbit Treated } \\
\text { with B. enteritidis } 205 \\
\text { Titer } 1: 16,000\end{array} \\
\text { Dilution of Serum }\end{array}$}} \\
\hline & & & & & & & & \\
\hline & 100 & 250 & 500 & 1000 & 100 & 250 & 500 & 1000 \\
\hline 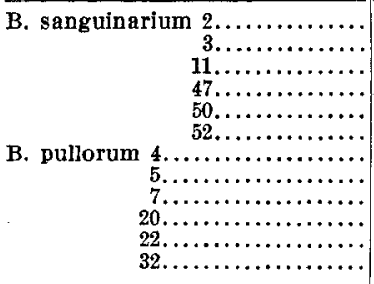 & $\begin{array}{l}+++ \\
+++ \\
+++ \\
+++ \\
+++ \\
++ \\
++ \\
+++ \\
+++ \\
++ \\
+++ \\
+++\end{array}$ & $\begin{array}{l}++ \\
++ \\
++ \\
+++ \\
++ \\
+ \\
++ \\
+++ \\
++ \\
++ \\
++ \\
++\end{array}$ & $\begin{array}{l}+ \\
+ \\
+ \\
++ \\
++ \\
+ \\
+ \\
++ \\
+ \\
++ \\
++\end{array}$ & 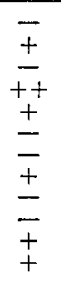 & $\begin{array}{l}+++ \\
+++ \\
+++ \\
+++ \\
+++ \\
++ \\
+++ \\
+++ \\
++ \\
+++ \\
+++ \\
+++\end{array}$ & $\begin{array}{l}++ \\
++ \\
+ \\
++ \\
++ \\
+ \\
++ \\
++ \\
++ \\
++ \\
+ \\
++\end{array}$ & $\begin{array}{l}\bar{t} \\
+ \\
++ \\
+ \\
+ \\
+ \\
++ \\
+ \\
+ \\
+ \\
+\end{array}$ & 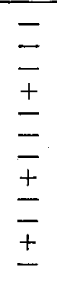 \\
\hline
\end{tabular}

Symbols are the same as those in Table 7. 
The agglutinative powers of serums of rabbits immunized toward several avian strains have been tested. The serums of rabbits, immunized toward Strains 4, 7, 9, 19, 22 and 31 of B. pullorum, and Strains $2,3,11,40$ and 47 of $B$. sanguinarium have in general reacted alike in all respects. These serums have not agglutinated in 1:500 dilution typical strains of $B$. paratyphosus $A$ and $B, B$. suipestifer, B. dysenteriae Flexner, B. dysenteriae Shiga, B. coli, B. proteus vulgaris, and B. avisepticus. Strains of B. typhosus, B. enteritidis, and B. abortus equinus, however, have been agglutinated by immune $B$. pullorum or B. sanguinarium sera.

Nine strains of $B$. enteritidis have been tested with several of these immune serums. A few strains of $B$. enteritidis have been agglutinated in as high dilutions as some of the avian strains. It thus appears that $B$. enteritidis is agglutinated in higher dilutions by these sera, than $B$. sanguinarium or $B$. pullorum is agglutinated by immune $B$. enteritidis serum when the titer of the serums is the same. The agglutinative action, on $\mathrm{B}$. enteritidis, of the serum of a rabbit immunized to B. pullorum, is given in table 9.

TABLE 9

Agglutination of B. Enteritidis with Immune Serum to B. Pullorum (9). TIter 1: 10,000

\begin{tabular}{|c|c|c|c|c|c|}
\hline & $1: 500$ & $1: 1000$ & $1: 2500$ & $1: 5000$ & $1: 10,000$ \\
\hline 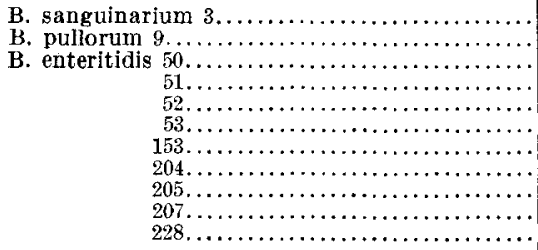 & $\begin{array}{l}+++ \\
+++ \\
+++ \\
+++ \\
+++ \\
+++ \\
+++ \\
+++ \\
+++ \\
+++ \\
++t\end{array}$ & $\begin{array}{l}+++ \\
+++ \\
++ \\
++ \\
++ \\
++ \\
+++ \\
++ \\
++ \\
++ \\
++\end{array}$ & $\begin{array}{l}++ \\
++ \\
+ \\
+ \\
+ \\
+ \\
++ \\
++ \\
+ \\
+\end{array}$ & $\begin{array}{l}+ \\
++ \\
- \\
- \\
- \\
+ \\
- \\
- \\
-\end{array}$ & $\begin{array}{l}\overline{+} \\
- \\
- \\
- \\
- \\
- \\
-\end{array}$ \\
\hline
\end{tabular}

The agglutination of $B$. typhosus with serums of rabbits immunized to B. sanguinarium or B. pullorum was first observed by Smith and Ten Broeck. Their results have since been confirmed by Rettger and Koser, and Krumwiede and Kohn. Pfeiler and Roepke, however, have observed that a serum, with a titer of 8,000 , from a rabbit immunized toward the "bacillus of fowl typhoid" did not agglutinate B. typhosus in a dilution of $1: 100$. In the present study three strains of $B$. typhosus have been agglutinated in high dilutions with serums of rabbits immune to the avian strains. The stock culture B. typhosus 
189 generally did not agglutinate as well as the other two strains. Typical results are given in table 10 .

TABLE 10

Agglutination Reaction of B. Pullorum (19) Serum. Titer 1: 5000

\begin{tabular}{|c|c|c|c|c|c|c|c|}
\hline \multirow{2}{*}{ Strain } & \multicolumn{7}{|c|}{ Dilution of Serum } \\
\hline & 100 & 250 & 500 & 1,000 & 2,500 & 5,000 & 10,000 \\
\hline B. sanguinarium ${ }_{41}^{1} \ldots \ldots \ldots \ldots$ & (...... & (...... & $\begin{array}{l}+++ \\
+++\end{array}$ & ++ & + & 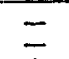 & $\overline{-}$ \\
\hline $47 \ldots \ldots \ldots$ & ....... & ....... & $\ldots . .$. & +++ & ++ & + & - \\
\hline B. pullorum $10 \ldots \ldots \ldots \ldots \ldots$ & ........ & ........ & +++ & +++ & $+t$ & + & - \\
\hline $\begin{array}{l}22 \ldots \ldots \ldots \ldots \ldots \\
31 \ldots \ldots \ldots \ldots\end{array}$ & …... & …... & $\begin{array}{ll}+++ \\
+++\end{array}$ & $\begin{array}{ll}++ \\
++\end{array}$ & + & \pm & \pm \\
\hline B. typhosus Hopkins......... & ….... & ….... & +++ & ++ & ++ & + & - \\
\hline $189 \ldots \ldots \ldots \ldots$ & $\cdots \cdots$ & $\ldots \ldots$ & ++ & $+t$ & $\overline{1 .+}$ & - & $\overline{-}$ \\
\hline B. enteritidis $52 \ldots \ldots \ldots \ldots \ldots$ & ........ & …... & $\begin{array}{l}+++ \\
t++\end{array}$ & $\begin{array}{l}++ \\
+++\end{array}$ & + & $\bar{t}$ & 二 \\
\hline 205............... & …..... & ......... & +++ & ++ & + & - & - \\
\hline $\begin{aligned} 228, \ldots \ldots \ldots \ldots & \ldots\end{aligned}$ & ...... & …... & ++ & $\stackrel{+}{+}$ & $\bar{t}$ & $\bar{z}$ & $=$ \\
\hline B. abortus equinus $192 \ldots \ldots$ & ........ & (....... & $\begin{array}{l}+++ \\
+++\end{array}$ & +++ & + & 二 & $\div$ \\
\hline $196 \ldots . .$. & ....... & ....... & +++ & $++t$ & ++ & + & $\rightarrow$ \\
\hline B. avisepticus $44 \ldots \ldots \ldots \ldots$. & + & - & - & & & & \\
\hline $46 \ldots \ldots \ldots \ldots$ & $\bar{z}$ & $\bar{z}$ & Z & & & & \\
\hline B. paratyphosus $\mathrm{A}$ 4 $\ldots \ldots \ldots$ & $=$ & - & - & & & & \\
\hline B. paratyphosus B $12 \ldots \ldots$. & + & - & - & & & & \\
\hline B. suipestifer $118 \ldots \ldots \ldots \ldots$ & - & - & & & & & \\
\hline
\end{tabular}

TABLE 11

Agglutination Reaction of B. Sanguinarium (40) Serum. Titer 1: 10,000

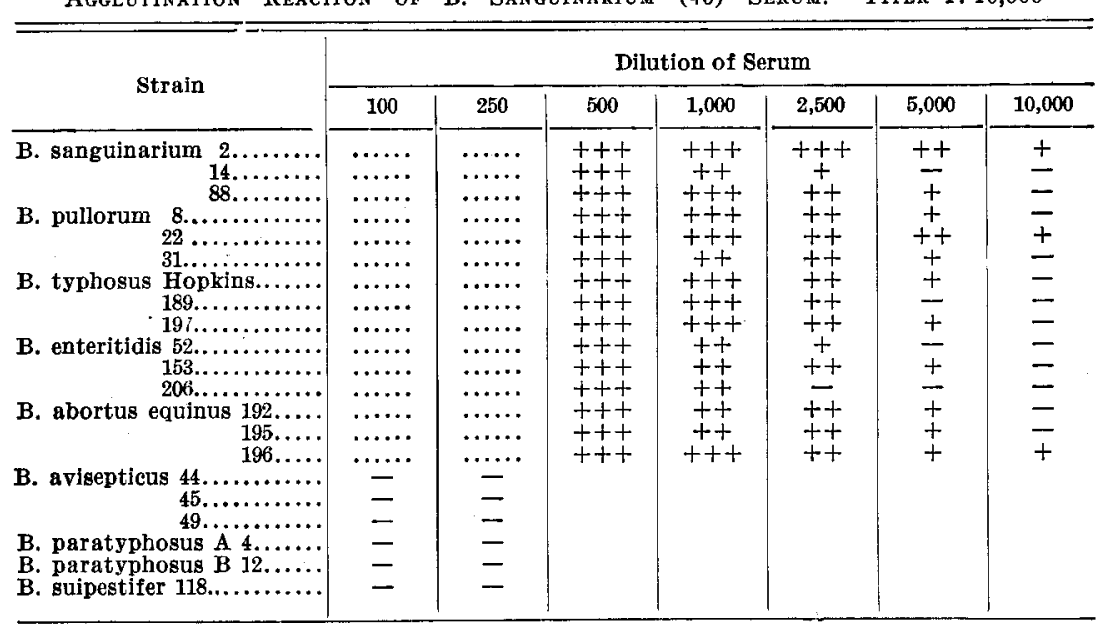

In studying the agglutinative relation of the avian strains to B. abortus-equinus it was observed that the serums of rabbits immunized to B. pullorum or B. sanguinarium contained agglutinins for five strains of B. abortus-equinus. Rettger and Koser, however, observed that a strain of B. abortus used as a control was not agglutinated by 
immune B. pullorum serum. In my work it was noted that B. pullorum and $B$. sanguinarium were not agglutinated by the serum of a rabbit immunized toward B. abortus-equinus.

Some typical agglutinative reactions of serums from rabbits immunized to B. pullorum are giver in Table 10.

Results similar to those in the preceding tables have been observed with serums of rabbits immunized toward other strains of B. sanguinarium and $\mathrm{B}$. pullorum, but it does not seem necessary to give tables. The agglutination of $B$. typhosus, B. enteritidis, and B. abortus-equinus with such serums is a rather remarkable case of cross agglutination. These results suggest that $\mathrm{B}$. enteritidis is more clearly related, at least antigenically, to these organisms and to $B$. typhosus than other members of the paratyphoid-enteritidis group.

\section{Absorption Tests}

In order to test further the antigenic relation of these organisms to $B$. typhosus, B. enteritidis, and B. abortus-equinus, absorption tests were made. The tests were carried out by suspending in about $25 \mathrm{cc}$ of isotonic salt solution, the 24-hour growth on an agar slant, whose surface area was approximately $60 \mathrm{sq} . \mathrm{cm}$. The suspension was centrifugalized and the supernatant liquid poured off. In some tests the organisms were washed a second time but this did not change the results. The organisms were then suspended in $5 \mathrm{cc}$ of salt solution and to this suspension was added $5 \mathrm{cc}$ of a $1: 25$ dilution of the serum to be tested. This mixture was placed in a small flask and incubated for 3 hours at $37 \mathrm{C}$. and then placed in the ice box for $20-48$ hours. They were then centrifugalized and the remaining titer for the various organisms determined.

TABLE 12

Absorption Tests with Serum of Rabbit Treated with B. Typhosus 189, Titer 1:20,000

\begin{tabular}{|c|c|c|c|c|}
\hline \multirow{2}{*}{$\begin{array}{c}\text { Exhausted } \\
\text { with }\end{array}$} & \multirow{2}{*}{$\underset{\text { Original }}{\text { Titer }}$} & \multicolumn{3}{|c|}{ Remaining Titer for } \\
\hline & & $\begin{array}{c}\text { B. typhosus } \\
\text { Hopkins }\end{array}$ & $\begin{array}{l}\text { B. pullor- } \\
\text { um } 22\end{array}$ & $\begin{array}{l}\text { B. sanguin- } \\
\text { arium } 47\end{array}$ \\
\hline $\begin{array}{l}\text { B. typhosus } 189 \ldots \ldots \ldots \ldots \ldots \\
\text { B. sanguinarium } 47 \ldots \ldots \ldots \ldots \ldots \\
\text { B. pullorum } 22 \ldots \ldots \ldots \ldots \ldots \ldots \ldots \\
\text { B. enteritidis } 52 \ldots \ldots \ldots \ldots \ldots \ldots\end{array}$ & $\begin{array}{r}20,000 \\
20,000 \\
20,000 \\
100\end{array}$ & $\begin{array}{r}<100 \\
10,000 \\
20,000 \\
20,000\end{array}$ & $\begin{array}{l}<100 \\
<100 \\
100 \\
<100\end{array}$ & $\begin{array}{r}<100 \\
250 \\
250 \\
100\end{array}$ \\
\hline
\end{tabular}

In absorption tests with typhoid immune serum it was observed that B. sanguinarium or B. pullorum removed the agglutinins for these avian strains but removed only a small percentage or none of the agglutinins for B. typhosus. Smith and Ten Broeck obtained similar results. B. enteritidis also removed a large percentage or all of the agglutinins for the avian strains. Typical results are given in table 12 . 
With the serums of rabbits immunized toward B. enteritidis, it was observed that the avian strains did not remove the agglutinins for B. enteritidis. The three strains of B. typhosus, which I have used, removed the agglutinins for the avian strains from these sera. table 13 shows typical reactions.

TABLE 13

Arsorption Thsts with Serum of Rabit Treated with B. Enteritidis (52)

\begin{tabular}{|c|c|c|c|c|}
\hline \multirow{2}{*}{$\begin{array}{c}\text { Exhausted } \\
\text { with }\end{array}$} & \multirow{2}{*}{$\begin{array}{l}\text { Original } \\
\text { Titer }\end{array}$} & \multicolumn{3}{|c|}{ Remaining Titer for } \\
\hline & & $\begin{array}{l}\text { B. enteriti- } \\
\text { dis } 52\end{array}$ & $\begin{array}{l}\text { B. sanguin- } \\
\text { arium } 47\end{array}$ & $\begin{array}{l}\text { B. pullor- } \\
\text { um } 22\end{array}$ \\
\hline $\begin{array}{l}\text { B. enteritidis } 52 \ldots \ldots \ldots \ldots \ldots \\
\text { B. sanguinarium } 47 \ldots \ldots \ldots \ldots \ldots \\
\text { B. pullorum } 22 \ldots \ldots \ldots \ldots \ldots \ldots \\
\text { B. typhosus Hopkins........ }\end{array}$ & $\begin{array}{r}10,000 \\
2,500 \\
2,500 \\
<100\end{array}$ & $\begin{array}{r}100 \\
10,000 \\
10,000 \\
10,000\end{array}$ & $\frac{-}{100}$ & $\begin{array}{l}- \\
-\end{array}$ \\
\hline
\end{tabular}

From the results indicated in the preceding tables it appears that B. typhosus and B. enteritidis have a certain antigenic relation to each other which is common to the avian strains. Thus the agglutinins for the avian strains, which have been studied in this respect, are removed from typhoid immune serum by $B$. enteritidis, and from immune B. enteritidis serum by $B$. typhosus. Further antigenic relations between $B$. typhosus and $B$. enteritidis are shown in absorption tests with serums of rabbits immunized toward B. pullorum or B. sanguinarium.

Absorption tests with serums of rabbits immunized toward B. pullorum (9) and (22) and B. sanguinarium (40) are given in table 14, 15 and 16.

Results similar to those tabulated in these tables have been obtained with serums of rabbits immunized toward B. pullorum 19 and 31, and toward B. sanguinarium 47 and.11. According to the tables the strains of $B$. typhosus and B. enteritidis remove a small percentage of the agglutinins for strains of $B$. pullorum or $B$. sanguinarium from serums of rabbits immunized with some strains of $B$. pullorum or B. sanguinarium. Smith and Ten Broeck observed that their strains of B. typhosus removed the agglutinins for the avian strains from serums of rabbits immunized toward B. sanguinarium or B. pullorum. I also noted in some earlier tests that B. typhosus or B. enteritidis irregularly removed all the agglutinins from such serums. In the earlier tests the organisms were not washed, and it was observed that those growths on slant agar surfaces, which had the most water of con- 
densation, removed a large percentage or all the agglutinins. The results were quite irregular with unwashed organisms, but with washed organisms the results were much more regular. The agar on which the organisms were grown had a reaction of +1 to phenolphthalein.

TABLE 14

Absorption Tests with Serum of Rabit treated with B. Pullorum (9)

\begin{tabular}{|c|c|c|c|c|c|}
\hline \multirow{2}{*}{$\begin{array}{l}\text { Exhausted } \\
\text { with }\end{array}$} & \multirow{2}{*}{$\begin{array}{c}\text { Original } \\
\text { Titer }\end{array}$} & \multicolumn{4}{|c|}{ Remaining Titer for } \\
\hline & & $\begin{array}{l}\text { B. pullor- } \\
\text { om } 22\end{array}$ & $\begin{array}{l}\text { B. typhosus } \\
\text { Hopkins }\end{array}$ & $\begin{array}{l}\text { B. enteriti- } \\
\text { dis } 52\end{array}$ & $\begin{array}{l}\text { B. abortus } \\
\text { equinus } 196\end{array}$ \\
\hline $\begin{array}{l}\text { B. pullorum } 9 \ldots \ldots \ldots \ldots \\
\text { B. typhosus Hopkins.... } \\
\text { B. enteritidis } 52 \ldots \ldots \ldots \\
\text { B. abortus equinus } 196 \ldots\end{array}$ & $\begin{array}{l}5,000 \\
5,000 \\
2,500 \\
2,500\end{array}$ & $\begin{array}{r}100 \\
1,600 \\
2,500 \\
5,000\end{array}$ & $\begin{array}{r}100 \\
100 \\
2,500 \\
2,500\end{array}$ & $\begin{array}{l}100 \\
800 \\
100 \\
800\end{array}$ & $\begin{array}{l}100 \\
200 \\
800 \\
200\end{array}$ \\
\hline
\end{tabular}

TABLE 15

Absorption Tests with Serum of Rabit Treated with B. Pullorum (22)

\begin{tabular}{|c|c|c|c|c|c|c|}
\hline \multirow{2}{*}{$\begin{array}{l}\text { Exhausted } \\
\text { with }\end{array}$} & \multirow{2}{*}{$\begin{array}{l}\text { Original } \\
\text { Titer }\end{array}$} & \multicolumn{5}{|c|}{ Remaining Titer for } \\
\hline & & $\begin{array}{l}\text { B. san- } \\
\text { guina- } \\
\text { rium } 47\end{array}$ & $\begin{array}{l}\text { B. pul- } \\
\text { lorum } \\
22\end{array}$ & $\begin{array}{c}\text { B. ty- } \\
\text { phosus } \\
\text { Hopkins }\end{array}$ & $\begin{array}{l}\text { B. en- } \\
\text { teriti- } \\
\text { dis } 52\end{array}$ & $\begin{array}{c}\text { B. abortus } \\
\text { equinus } \\
196\end{array}$ \\
\hline $\begin{array}{l}\text { B. pullorum } 9 \ldots \ldots \ldots \ldots \ldots \ldots \\
\text { B. ganguinarium } 3 \ldots \ldots \ldots \ldots \\
\text { B. typhosus Hopkins....... } \\
\text { B. enteritidis } 52 \ldots \ldots \ldots \ldots \ldots \\
\text { B. abortus equinus } 196 \ldots \ldots \ldots\end{array}$ & $\begin{array}{r}5,000 \\
10,000 \\
5,000 \\
4,000 \\
5,000\end{array}$ & $\begin{array}{r}250 \\
100 \\
5,000 \\
10,000 \\
10,000\end{array}$ & $\begin{array}{r}500 \\
100 \\
2,500 \\
5,000 \\
5,000\end{array}$ & $\begin{array}{r}250 \\
<100 \\
100 \\
1,000 \\
5,000\end{array}$ & $\begin{array}{r}250 \\
<100 \\
2,500 \\
100 \\
2,500\end{array}$ & $\begin{array}{r}<100 \\
<100 \\
5,000 \\
2,500 \\
250\end{array}$ \\
\hline
\end{tabular}

TABLE 16

Absorption Tests with. Serum of Rabit Treated with B. Sanguinarium (40)

\begin{tabular}{|c|c|c|c|c|c|c|}
\hline \multirow{2}{*}{$\begin{array}{c}\text { Exhausted } \\
\text { with }\end{array}$} & \multirow{2}{*}{$\begin{array}{c}\text { Original } \\
\text { Titer }\end{array}$} & \multicolumn{5}{|c|}{ Remaining Titer for } \\
\hline & & $\begin{array}{l}\text { B. san- } \\
\text { guina- } \\
\text { rium } 47\end{array}$ & $\begin{array}{l}\text { B. pul- } \\
\text { lorum } \\
22\end{array}$ & $\begin{array}{l}\text { B. ty- } \\
\text { phosus } \\
\text { Hopkins }\end{array}$ & $\begin{array}{l}\text { B, en- } \\
\text { teriti- } \\
\text { dis } 52\end{array}$ & $\begin{array}{c}\text { B. abortus } \\
\text { equinus } \\
196\end{array}$ \\
\hline $\begin{array}{l}\text { B. pullorum } 22 \ldots \ldots \ldots \ldots \ldots \\
\text { B. sanguinarium } 47 \ldots \ldots \ldots \ldots \\
\text { B. typhosus Hopkins......... } \\
\text { B. enteritidis } 52 . \ldots \ldots \ldots \ldots \ldots \\
\text { B. abortus equinus } 196 \ldots \ldots \ldots\end{array}$ & $\begin{array}{r}10,000 \\
10,000 \\
5,000 \\
5,000 \\
5,000\end{array}$ & $\begin{array}{r}100 \\
<100 \\
10,000 \\
10,000 \\
10,000\end{array}$ & $\begin{array}{r}100 \\
<100 \\
5,000 \\
5,000 \\
5,000\end{array}$ & $\begin{array}{r}<100 \\
<100 \\
100 \\
1,000 \\
2,500\end{array}$ & $\begin{array}{r}100 \\
<100 \\
1,000 \\
250 \\
2,500\end{array}$ & $\begin{array}{r}<100 \\
<100 \\
1,000 \\
1,000 \\
100\end{array}$ \\
\hline
\end{tabular}

B. typhosus apparently removed a large percentage of the agglutinins from such serums for B. enteritidis, and on the other hand, B. enteritidis appeared to remove a large percentage of the agglutinins from these serums for B. typhosus. B. abortus-equinus did not remove agglutinins for other organisms to any great extent. 
While absorption tests are not necessary to differentiate B. abortus equinus or B. enteritidis from these avian strains, yet it was thought that these might throw some light on the antigenic properties of the avian types. From absorption tests as well as from agglutination tests it appears that $B$. enteritidis occupies an intermediate position between $B$. typhosus and B. abortus-equinus in its relation to the avian strains. These absorption tests also indicate an antigenic relation between $B$. typhosus and $B$. enteritidis.

\section{PATHOGENESIS}

A high percentage of fatal infections following the feeding of B. pullorum to rabbits, guinea-pigs, and cats has been reported by Rettger, Hull and Sturges. Smith and Ten Broeck have observed rapidly fatal results following the intravenous injection of broth cultures of B. sanguinarium into rabbits. The latter investigators considered the sudden onset of symptoms to be due to a toxin, since if animals recovered from the immediate effects they died a few days later from an infection. In the present study, pathogenesis has been tested by feeding and intraperitoneal inoculations.

\section{Feeding Experiments}

In the feeding experiments the cultures have been grown on agar slants, in milk and in meat infusion broth. The broth and milk cultures were incubated from 1-5 days, before they were fed to the animals. The longer incubation period was used to determine the development of toxic substances which might show their presence by producing symptoms of food poisoning when ingested. The method of administering the test organisms varied. In some instances especially in feeding rabbits and guinea-pigs large amounts, water suspensions of 24-hour slant agar cultures were mixed with finely ground carrots, while at other times these suspensions or broth cultures were mixed with milk. In some experiments with cats, rats, and mice finely ground meat was employed which had been sterilized and inoculated with the organisms to be tested and incubated for 24-48 hours. In feeding the birds the suspensions of the cultures were added to dried bread crumbs. The amounts of cultures fed varied from 1-12 agar slant cultures, or in the case of broth or milk cultures from $5-30 \mathrm{cc}$. In some cases, where counts were made by plating on agar, approximately 100 billion bacteria were fed.

Different strains of B. pullorum have been fed to 7 guinea-pigs weighing between 200 and $350 \mathrm{gm}$.; 6 rabbits weighing between 1,500 and $2,500 \mathrm{gm}$.; 2 young rabbits weighing about $700 \mathrm{gm}$.; 5 kittens weighing between 620 and 925 gm.; 6 mice; 4 rats; 2 cats; 6 sparrows; 5 young pigeons less than 48 hours of age; 2 adult pigeons; 10 chicks about 2 weeks of age, and 4 young hens about 4 months old. Cultures of $B$. sanguinarium have been fed in a similar manner to about the same number of animals. 
No symptoms of disease were observed following the ingestion of these organisms, except that one guinea-pig, which was fed $15 \mathrm{cc}$ of a 48-hour milk culture of B. pullorum (9), appeared sick 4 days after it was fed the culture and died the following day. No lesions, other than a slight congestion of the abdominal viscera, were observed at necropsy. B. pullorum was isolated in pure culture from the heart blood and liver.

Cats, which were fed sparrows, or rabbits that had died from an infection with B. pullorum or B. sanguinarium, showed no symptoms of disease. Also the freshly isolated strains, B. pullorum (31) fed within 2 weeks after isolation from a dead chick, and B. sanguinarium (47 and 57) fed 4-7 days after isolation, did not produce any injurious effect when fed to rabbits, guinea-pigs, mice, young and adult pigeons and sparrows. Chickens apparently are not very susceptible to laboratory cultures of these avian strains.

Rettger and others consider that chickens more than 5 days old are generally not readily susceptible to B. pullorum. Jones, ${ }^{12}$ Rettger, ${ }^{2}$ and Hadley, ${ }^{13}$ however, have observed fatal infections in adult fowls with this organism. Pfeiler and Roepke ${ }^{7}$ working with B. sanguinarium have observed that chickens cannot regularly be infected by feeding cultures of this organism, but feeding the viscera of fowls dead of the disease generally produces the disease. They also observed that turkeys, guineas, and peacocks contracted the disease under natural conditions, but ducks and geese did not. They succeeded, however, in producing a fatal infection in a duck by inoculation. One of the strains of B. sanguinarium (41) which I have studied was isolated from a wild duck, which with several hundred others had apparently died from an infection with this organism.

From the feeding experiments it appears that rabbits, guinea-pigs, cats, rats, mice, sparrows, pigeons and chickens are not susceptible to laboratory cultures of B. pullorum or B. sanguinarium when administered by mouth.

\section{INOCULATION EXPERIMENTS}

Inoculations of cultures of these organisms into laboratory animals have not given uniform results with the different investigators. Smith and Ten Broeck observed that $0.3-0.5 \mathrm{cc}$ of a 24-hour broth culture of B. sanguinarium produced a fatal infection in rabbits when injected intravenously. Taylor, ${ }^{17}$ however, observed that $1 \mathrm{cc}$ of a 24 -hour broth culture of this organism did not produce death in rabbits when injected intraperitoneally. Guinea-pigs have been found by several investigators to be quite resistant to injections of cultures of B. sanguinarium. Pfeiler and Roepke state that rats, cats, and dogs are resistant to inoculations with this organism. Smith and Ten Broeck observed that $2 \mathrm{cc}$ of a 24 -hour broth culture of the fowl typhoid organism did not prove fatal to a chicken inoculated intravenously. 
Comparatively few inoculation experiments with $B$. pullorum have been made. Rettger ${ }^{2}$ and Gage consider the rabbit very susceptible to inoculations with B. pullorum.

TABLE 17

Inoculation Experiments with Mice

\begin{tabular}{|c|c|c|c|}
\hline Animals & Strain & $\begin{array}{c}\text { Condition and Amount of } \\
\text { Culture }\end{array}$ & Results \\
\hline & B. sanguinarium 2 & $\begin{array}{l}0.5 \mathrm{e} \mathrm{c} \text { of } 24 \text {-hour broth culture } \\
\text { to each }\end{array}$ & Affected slightly \\
\hline 1 mouse & B. sanguinarium 2 & 1 c c of 24 -hour broth culture & $\begin{array}{l}\text { * Found dead on } \\
\text { next day }\end{array}$ \\
\hline 1 mouse & B. sanguinarium 47 & $\begin{array}{l}0.5 \text { c c of 24-hour broth culture } \\
\text { isolated } 5 \text { days before } \\
\text { injected }\end{array}$ & Slightly sick \\
\hline 1 mouse & B. sanguinarium 47 & $\begin{array}{l}1 \text { e c of } 24 \text {-hour broth culture } \\
\text { isolated } 5 \text { days before } \\
\text { jnjected }\end{array}$ & *Died in 24 hours \\
\hline 2 mice & B, pullorum 9 & $\begin{array}{l}0.5 \text { c e of } 24 \text {-hour broth culture } \\
\text { to each }\end{array}$ & Slightly sick \\
\hline 2 mice & B. pullorum 5 & $\begin{array}{l}0.5 \text { c c of agar slant culture } \\
\text { suspended in } 10 \mathrm{c} \mathrm{c} \text { salt solu- } \\
\text { tion }\end{array}$ & Slightly sick \\
\hline 1 mouse & B. pullorum 5 & 1 c c of agar cultures suspen- & *Died after $18 \mathrm{hrs}$. \\
\hline 1 mouse & B. pullorum 7 & $0.5 \mathrm{c}$ c of 24 -hour broth culture & Slightly sick \\
\hline $\begin{array}{l}1 \text { mouse } \\
1 \text { mouse }\end{array}$ & $\begin{array}{l}\text { B. pullorum } 31 \\
\text { B. pullorum } 31\end{array}$ & $0.5 \mathrm{c}$ c of 24 -hour broth culture & Slightly sick \\
\hline & & 1 ce of 24-hour Drotn c & "wed on 4m day \\
\hline
\end{tabular}

* Organisms were recovered from heart blood and liver.

TABLE 18

Inoculation Experiments with Guinea:Pigs

\begin{tabular}{|c|c|c|c|c|}
\hline & Animals & Strain & $\begin{array}{l}\text { Condition and Amount of } \\
\text { Culture }\end{array}$ & Results \\
\hline $\begin{array}{c}5 . \\
6 . \\
7 . \\
8 . \\
9 . \\
10 . \\
11 . \\
12 . \\
13 . \\
14 .\end{array}$ & $\begin{array}{l}\text { Wt. } 290 \mathrm{Gm} . \\
\text { Wt. } 275 \mathrm{Gm} . \\
\text { Wt. } 290 \mathrm{Gm} . \\
\text { Wt. } 320 \mathrm{Gm} \text {. } \\
\text { Wt. } 340 \mathrm{Gm} . \\
\text { Wt. } 400 \mathrm{Gm} . \\
\text { Wt. } 310 \mathrm{Gm} . \\
\text { Wt. } 325 \mathrm{Gm} . \\
\text { Wt. } 345 \mathrm{Gm} . \\
\text { Wt. } 310 \mathrm{Gm} . \\
\text { Wt. } 370 \mathrm{Gm} . \\
\text { Wt. } 350 \mathrm{Gm} . \\
\text { Wt. } 330 \mathrm{Gm} . \\
\text { Wt. } 320 \mathrm{Gm}\end{array}$ & $\begin{array}{l}\text { B. sanguinarium } 3 \\
\text { B. sanguin arium } 11 \\
\text { B. sanguinarium } 11 \\
\text { B. sanguinarium } 47 \\
\text { B. sanguinarium } 47 \\
\text { B. sanguinarium } 11 \\
\text { B. pullorum 9 } \\
\text { B. pullorum 9 } \\
\text { B. pullorum 9 } \\
\text { B. pullorum } 10 \\
\text { B. pullorum } 10 \\
\text { B. pullorum } 16 \\
\text { B. pullorum } 16 \\
\text { B. pullorum } 19\end{array}$ & 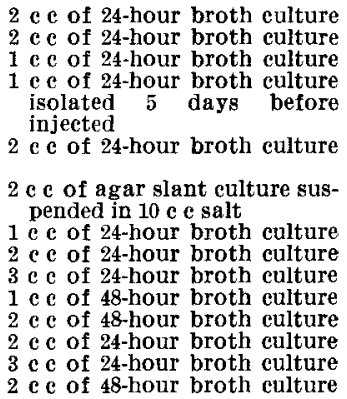 & $\begin{array}{l}\text { *Died } 20 \text { hours later } \\
\text { *Died } 18 \text { hours later } \\
\text { Survived } \\
\text { Survived } \\
\text { Lost } 60 \text { Gm. in } 3 \\
\text { days. Recovered } \\
\text { *Dead in } 16 \text { hours } \\
\text { Survived } \\
\text { Survived } \\
\text { *Dead in } 48 \text { hours } \\
\text { Survived } \\
\text { Survived } \\
\text { Survived } \\
\text { *Died in } 4 \text { days } \\
\text { *Died in } 48 \text { hours }\end{array}$ \\
\hline
\end{tabular}

* Organisms were recovered from beart blood and liver.

In my own work, broth cultures, and agar slant cultures suspended in $10 \mathrm{cc}$ of salt solution, have been used. Inoculations were made intraperitoneally unless otherwise stated. Details of inoculation experiments are given in tables $17,18,19$ and 20 .

In addition to the experiments tabulated, white rats and pigeons were inoculated with 1-2.5 $\mathrm{cc}$ of 24-hour broth cultures of different strains of B. pullorum and B. sanguinarium. The rats were inoculated intraperitoneally 
and the pigeons were injected intramuscularly. All the rats and pigeons survived the inoculations except that one pigeon died 4 days after being inoculated with $1.5 \mathrm{cc}$ of a 24 -hour broth culture of $B$. sanguinarium (47). This culture of B. sanguinarium had been isolated 5 days previously, from a hen which had died of fowl typhoid.

TABLE 19

Inoculation Experiments with Rabits

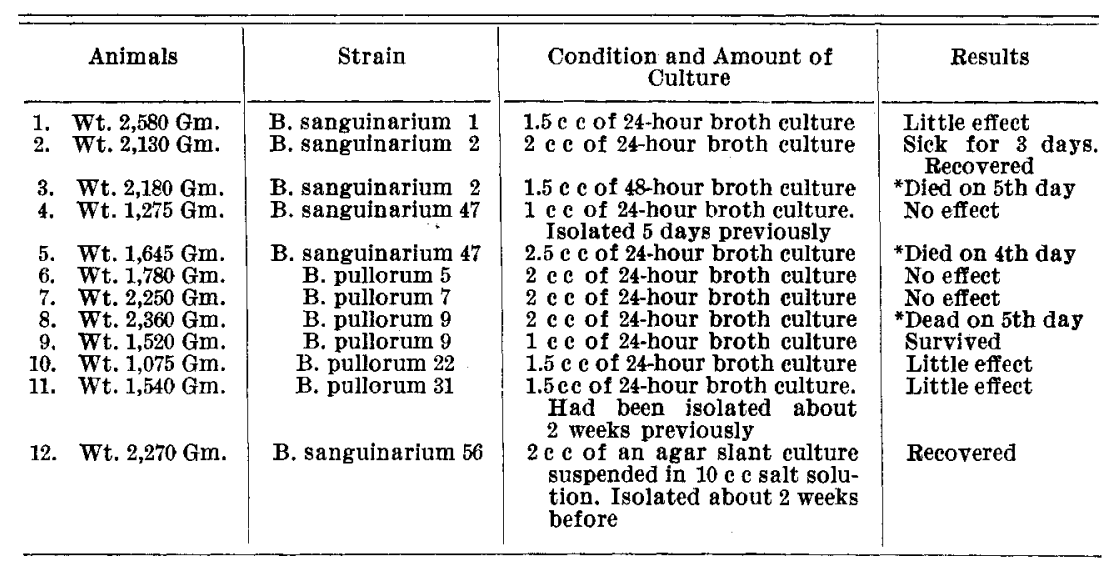

* Organisms were recovered from heart blood and liver.

TABLE 20

Inoculation Experiments with Sparrows

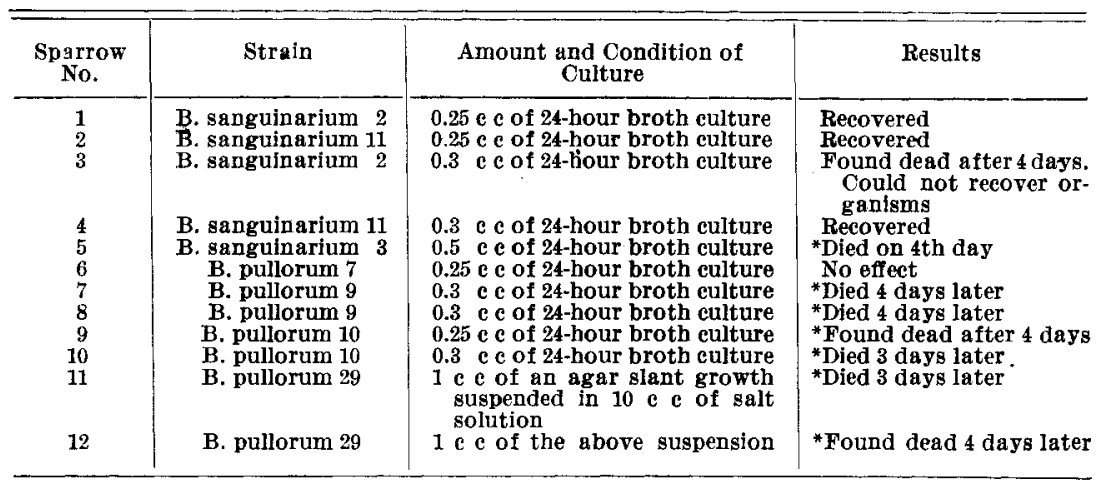

* The organisms were recovered from the heart blood and the liver of these animals.

Four young hens weighing between 840 and $1,350 \mathrm{gm}$. were inoculated intramuscularly with $2 \mathrm{cc}, 4 \mathrm{cc}, 5 \mathrm{cc}$, and $8 \mathrm{cc}$, respectively, of 5-day broth cultures of B. sanguinarium. Two $\mathrm{c} c$ of 24-hour broth cultures of B. pullorum (9 and 31 ) and B. sanguinarium (11 and 56) were also injected intramuscularly into hens weighing from 800 to $1,300 \mathrm{gm}$. A rooster weighing 1,875 $\mathrm{fm}$. was inoculated with $2 \mathrm{cc}$ of a 24 -hour broth culture of $\mathrm{B}$. sanguinarium 
(57). This culture had been isolated 5 days previously from a hen that had died of fowl typhoid. All of the chickens recovered. The one that received $8 \mathrm{cc}$ of the broth culture of B. sanguinarium (11) appeared sick for a few hours after inoculation.

From these experiments it appears that mice, rats, guinea-pigs, pigeons, sparrows, chickens and rabbits are quite resistant to laboratory cultures of these organisms. The rabbit is apparently the most susceptible. The amount necessary to kill adult rabbits varies considerably, but is generally between 2 and $3 \mathrm{c} \mathrm{c}$ of a 24-hour broth culture. It generally requires a similar amount to kill the guinea-pig. Rats and mice are quite resistant. Pigeons, sparrows and chickens were also quite resistant to the laboratory cultures 'of these organisms, altho a pigeon was more susceptible to a freshly isolated culture of $B$. sanguinarium. The sparrow appeared to be slightly more susceptible to B. pullorum. In general, the pathogenesis of these two avian strains is the same for the laboratory animals.

\section{TOXIN PRODUCTION}

Smith and Ten Broeck observed that the injection into rabbits of $2 \mathrm{cc}$ of the bacterial free filtrates of 5-day broth cultures of B. sanguinarium or of B. pullorum regularly produced death in a few hours. They further observed that guinea-pigs were refractory toward this toxin. The medium which they found to be the most suitable for toxin production was freshly prepared sugar-free veal broth to which was added $0.1 \%$ of dextrose. Another factor, which they considered very important, was that the depth of the layer of fluid in which the cultures were grown should not be more than $2 \mathrm{~cm}$. In my work a similar medium was used except that Armour's peptone was used instead of Witte's. Results of injections of bacterial free filtrate into rabbits and chickens are given in Tables 21 and 22.

Since the results of the inoculations of toxic filtrates into guineapigs and white mice were largely negative, it seems unnecessary to tabulate the results. The guinea-pigs used in these tests weighed between 225 and $325 \mathrm{gm}$. Four guinea-pigs, each injected with $2 \mathrm{c} \mathrm{c}$ of the toxic filtrate of different strains of B. sanguinarium, survived. Two guinea-pigs, of five injected with $2 \mathrm{cc}$ of the toxic filtrate of different strains of B. pullorum, died within 48 hours. White mice in a few cases were killed by injecting $1 \mathrm{c} c$ of the toxic filtrates, but in other cases they survived such injections. 
TABLE 21

\begin{tabular}{|c|c|c|c|}
\hline INTRAPERI & INJI & 5-DAX & Filtrates into \\
\hline Strain & $\begin{array}{l}\text { Amount } \\
\text { Injected, } \\
\text { O C }\end{array}$ & $\begin{array}{l}\text { Weight in } \\
\text { Grams of } \\
\text { Rabbit }\end{array}$ & Results \\
\hline B. sanguinarium 11 & 2 & 1,980 & $\begin{array}{l}\text { Breathing very difficult after } 2 \text { hours. Died } \\
\text { an hour later. Marked rigor } 5 \text { minutes } \\
\text { after death. Liver and spleen congested }\end{array}$ \\
\hline B. sanguinarium 11 & 2 & 2,635 & $\begin{array}{l}\text { Breathing very difficult } 2 \text { hours later. Dead } \\
\text { in } 4 \text { hours. Hemorrhages in gastric } \\
\text { mucosa }\end{array}$ \\
\hline B. sanguinarium 47 & 2 & 1,720 & $\begin{array}{l}\text { Very sick an hour later. Died in } 2 \text { hours. } \\
\text { Marked rigor few minutes after death. } \\
\text { Hemorrhages in gastric mucosa and } \\
\text { under endoeardium }\end{array}$ \\
\hline B. sanguinarium 47 & 2 & 1,740 & $\begin{array}{l}\text { Very sick for several hours. Lost } 160 \mathrm{gm} \text {. } \\
\text { in } 3 \text { days. Recovered }\end{array}$ \\
\hline B. pullorum 19 & 1.8 & 2,315 & $\begin{array}{l}\text { Quite sick } 2 \text { hours later. Appeared better the } \\
\text { next morning. Recovered }\end{array}$ \\
\hline B. pullorum 19 & 2 & 2,150 & $\begin{array}{l}\text { Found dead } 20 \text { hours later. Hemorrhages } \\
\text { in gastric mucosa and thymus }\end{array}$ \\
\hline B. pullorum 24 & 1.5 & 2,175 & $\begin{array}{l}\text { Died in } 4 \text { hours. Hemorrhages in thymus } \\
\text { and gastric mucosa. Marked rigor few } \\
\text { minutes after death }\end{array}$ \\
\hline B. pullorum 24 & 2 & 2,290 & $\begin{array}{l}\text { Quite sick for several hours. Lost } 115 \mathrm{gm} \text {. } \\
\text { in } 24 \text { hours. Recovered }\end{array}$ \\
\hline B. pullorum 8 & 1 & 1,655 & $\begin{array}{l}\text { Slightly affected. Lost } 30 \mathrm{gm} \text {. in } 24 \text { hours. } \\
\text { Recovered }\end{array}$ \\
\hline B. pullorum 8 & 2 & 1,690 & $\begin{array}{l}\text { Quite sick. Lost } 130 \mathrm{gm} \text {. in } 48 \text { hours. Nor- } \\
\text { mal weight in } 14 \text { days }\end{array}$ \\
\hline B. pullorum 9 & 1.5 & 1,720 & $\begin{array}{l}\text { Died } 2 \text { hours later. Hemorthages in thymus } \\
\text { and endocardium. Both kidneys showed } \\
\text { chronic interstitial nephritis }\end{array}$ \\
\hline & 2 & 1,795 & $\begin{array}{l}\text { Found dead } 10 \text { hours later. Hemorrhages } \\
\text { in thymus and gastric mucosa }\end{array}$ \\
\hline B. pullorum 28 & 2 & 1,875 & $\begin{array}{l}\text { Dead after } 15 \text { hours. Gastric mucosa and } \\
\text { thymus hemorrhagic }\end{array}$ \\
\hline $\begin{array}{l}\text { B. pullorum } 28 \\
\text { B. pullorum } 25\end{array}$ & $\begin{array}{l}1 \\
1.5\end{array}$ & $\begin{array}{l}1,675 \\
1,615\end{array}$ & $\begin{array}{l}\text { Quite sick. } \\
\text { Quite sick. } \\
\text { Recovered }\end{array}$ \\
\hline & 2 & 1,690 & $\begin{array}{l}\text { Djed in } 6 \text { hours. Hemorrhages into gastric } \\
\text { mucosa }\end{array}$ \\
\hline $\begin{array}{l}\text { B. pullorum } 32 \\
\text { B. pullorum } 32\end{array}$ & $\begin{array}{l}1.5 \\
1.5\end{array}$ & $\begin{array}{l}1,880 \\
1,375\end{array}$ & $\begin{array}{l}\text { Slightly affeeted } \\
\text { Quite siek. Lost } 50 \mathrm{gm} \text {. in } 24 \text { hours }\end{array}$ \\
\hline B. sanguinarium 3 & 2 & 1,890 & $\begin{array}{l}\text { Death occurred in } 4 \text { hours. Hemorrhages } \\
\text { in gastric mucosa and pericardium }\end{array}$ \\
\hline B. sanguinarium 41 & 2 & 2,240 & $\begin{array}{l}\text { Death in } 5 \text { hours. Hemorrhages in thymus } \\
\text { and gastric mucosa }\end{array}$ \\
\hline B. sanguinarium 31 & 2 & 1,745 & $\begin{array}{l}\text { Death in } 2 \text { hours. Hemorrhages in the } \\
\text { thymus }\end{array}$ \\
\hline
\end{tabular}

TABLE 22

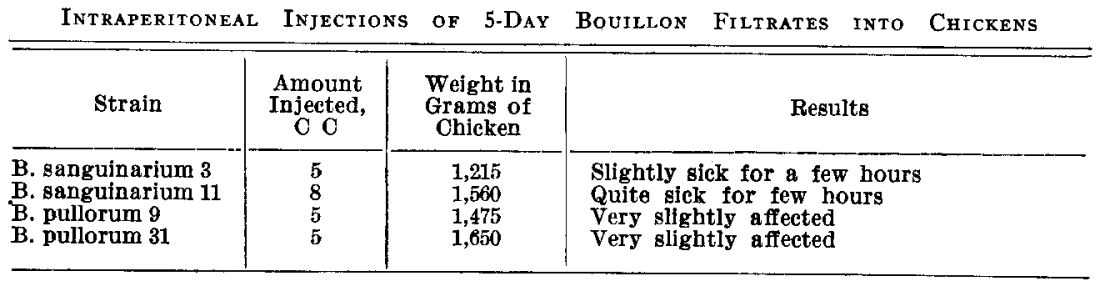

In these experiments control animals have been inoculated in each case. The filtrates were tested for sterility before being injected, and blood from the heart and liver of the animals that died was tested also 
for sterility. It appears that mice, guinea-pigs, and chickens are quite resistant toward the toxin. Rabbits, however, are more susceptible. The fatal dose when injected intraperitoneally is about $2 \mathrm{cc}$ of a 5-day bouillon filtrate for rabbits weighing about 2,000 gm. There is some variation in the amount of toxin produced by different strains. The symptoms appear from 1-2 hours after inoculation. There may be no special symptoms or there may be respiratory and intestinal disturbances. The respiratory symptoms are manifested by marked dyspnea; the intestinal disturbances, by the discharge of many fecal balls or even liquid feces and large amounts of urine. Death may be preceded by a violent struggle, or the animal may gradually expire. Death usually occurs within 24 hours. Necropsy shows often a congested liver and spleen. Hemorrhages into the thymus have been observed in a large percentage of the cases. The heart is dilated and there may be hemorrhages under the pericardium or endocardium. Microscopic examination of the tissues shows congestion of liver, kidneys and spleen. It appears that the toxin formed by B. pullorum or B. sanguinarium produces the same effect when injected into laboratory animals. The strength of the toxin formed is approximately the same for the two organisms, but there is some variation with different strains of both organisms.

\section{SUMMARY AND CONCLUSIONS}

There is little exact knowledge at present concerning the distribution of B. pullorum and B. sanguinarium, but it appears that both cause considerable losses to poultry raisers in many parts of the United States. There has apparently been some confusion at times in differentiating B. avisepticus from B. sanguinarium. B. avisepticus, however, may generally be distinguished from $B$. sanguinarium by its action in milk, indol production, fermentation of carbohydrates, agglutination reaction and pathogenesis. B. pullorum and B. sanguinarium do not produce indol; generally form hydrogen sulphid in a lead acetate medium, and produce a temporary acidity in milk, but later alkali is formed. B. sanguinarium usually produces alkali in a shorter time than B. pullorum. The casein is digested by most strains of these organisms. As regards fermentation, B. pullorum produces acid and generally gas in several carbohydrates. B. sanguinarium produces acid but no gas in the same carbohydrates, and in addition produces acid in dulcite and maltose. There is some variation in the 
reactions in maltose. Some strains of $B$. pullorum produce slight amounts of acid after several days' incubation and two strains have produced acid and gas quite promptly in maltose.

Agglutination tests with these organisms have shown that there is an antigenic relation between these organisms and B. typhosus, B. enteritidis, and $B$. abortus-equinus. Such antigenic relations were not observed between these avian strains and $B$. avisepticus, B. dysenteriae, B. paratyphosus A and B, B. suipestifer, B. proteus, and B. coli. Absorption tests will differentiate quite readily between $B$. typhosus and these avian strains. Agglutination and absorption tests with serums of rabbits immunized toward these avian types suggest an antigenic relation between $B$. typhosus, B. enteritidis, and these avian strains.

Feeding experiments indicate that laboratory cultures of these organisms will rarely produce an injurious effect on laboratory animals. Two freshly isolated strains of $B$. sanguinarium and one of $B$. pullorum were also fed to various animals without producing serious effects. It has been observed from inoculations that the rabbit is the most susceptible laboratory animal to the strains studied. It generally requires from 2-3 c c of a 24-hour broth culture injected intraperitoneally to produce a fatal infection in a rabbit weighing about $2,000 \mathrm{gm}$. A few freshly isolated strains were not more virulent for rabbits, guinea-pigs, mice and rats than cultures kept in the laboratory for some time. B. pullorum and B. sanguinarium produce a toxin when grown under proper conditions which is quite poisonous to rabbits. The action of the toxin produced appears to be the same for the two strains.

These avian strains may be differentiated from B. typhosus by their lack of motility, their fermentation reactions in rhamnose and sorbite, and absorption tests with immune serums. Serologic tests and certain fermentative reactions may be used to differentiate these organisms from $\mathrm{B}$. dysenteriae. They may be differentiated from other members of the paratyphoid-enteritidis group by morphologic and cultural characteristics, and serologic tests. B. avisepticus, as has been mentioned before, may be differentiated in many ways from $B$. sanguinarium and $B$. pullorum.

$B$. pullorum may be distinguished from $B$. sanguinarium by the inability of the former to ferment dulcite, while the latter ferments 
this carbohydrate. Also, the former organism does not generally produce acid in maltose and generally produces gas in several of the carbohydrates. B. sanguinarium, on the other hand, generally produces acid promptly in maltose and does not produce gas in any of the carbohydrates. Rhamnose is fermented promptly by B. pullorum, while $B$. sanguinarium does not produce acid before 48 hours' incubation. It appears, therefore, that there are sufficient differences between B. sanguinarium and B. pullorum to regard them as separate types. 